\title{
Environmental Indicators for the Evaluation of Wood Products in Consideration of Site-Dependent Aspects: A Review and Integrated Approach
}

\author{
Nadine May ${ }^{1}$, Edeltraud Guenther ${ }^{1, *}$ (D) and Peer Haller ${ }^{2}$ \\ 1 Chair of Environmental Management and Accounting, Technische Universität Dresden, 01062 Dresden, \\ Germany; ema@mailbox.tu-dresden.de \\ 2 Institute of Steel and Timber Construction, Technische Universität Dresden, 01062 Dresden, Germany; \\ holzbau@mailbox.tu-dresden.de \\ * Correspondence: ema@mailbox.tu-dresden.de; Tel.: +49-351-463-34313
}

Received: 31 August 2017; Accepted: 18 October 2017; Published: 21 October 2017

\begin{abstract}
On the way towards a more biobased economy, the sustainable use of global wood resources remains a challenge as several trade-offs arise, e.g., from an increased energetic use of wood, an increased use of innovative but probably less recyclable wood composites, or from the need to conserve other forest ecosystem services. The aim of this study is to identify existing environmental indicators and methods for an evaluation of the sustainability of wood products in consideration of all life cycle stages, site-dependent aspects and later use in corporate decision-making. We chose a systematic literature review to answer the research questions explicitly and comprehensively. Qualitative content analysis was used to code indicators and scientific methods according to the Pressure-State-Response (PSR) framework. The sample $(\mathrm{N}=118)$ is characterized by a high number of life cycle assessment (LCA) case studies. In $51 \%$ of all studies, the study authors use a combination of different methods. A total of 78 indicators and 20 site-dependent aspects could be identified in the sample. The study findings represent a first step towards a holistic environmental assessment of wood products.
\end{abstract}

Keywords: environmental indicators; wood products; literature review; site-dependent aspects; life cycle assessment; Pressure-State-Response framework; decision-making

\section{Introduction}

Due to global challenges such as climate change, resource scarcity, and political uncertainties [1], many organizations are increasingly forced to take resource-related aspects into account in their decisions concerning the production or procurement of products and raw materials in order to gain a competitive advantage in the future [2]. Such decisions can include the diversification of supply sources, the increase of process and material efficiencies including recycling, or the substitution of scarce and non-renewable materials by alternatives with similar properties and higher availability $[3,4]$. An alternative, renewable resource which is highly versatile and widely utilized in the material-intensive sectors of construction, furniture, and packaging and that has shown increasing harvesting rates over the last decades is wood $[5,6]$. Its inherent material properties together with its ecological advantages, e.g., a low embodied energy and global warming potential, make it particularly competitive to state-of-the-art construction materials such as steel and concrete [7]. However, there are also some challenging aspects associated with the resistance and availability of wood.

Due to its nature, it often has to undergo chemical treatment when used for outdoor constructions with direct exposure to humidity, and consequently can bear a certain toxicity potential [8]. More resistant tropical wood species are rare and can hardly be used in a sustainable way due 
to widespread illegal logging [9]. Origin and trading routes are often not completely and transparently documented, mainly as a result of poor governance of forests, high wood processing capacities, and inadequate tracking systems [10]. Even if labeling has become more common over the last years, it is still voluntary for most companies [11]. In addition, harvest statistics are often reported on the country level instead of regional or local level of ecosystems [5]. For the global wood resources, scarcity is already evidenced [5,12]. This scarcity can cause conflicts among different stakeholder groups since forests provide diverse ecosystem services such as being habitats for complex communities of species, producing wood for material and energetic utilization, providing space for recreation, and posing a regulatory force on the meso- and microclimate [13]. In addition, regional forest conversion measures in Central Europe have led to a spread of so far less profitable, but more biodiversity-supportive endemic broad-leafed tree species $[7,14,15]$. Strategies on the development towards a more biobased economy, such as the European Bioeconomy Strategy [16], are quite reasonable when considering the associated carbon dioxide $\left(\mathrm{CO}_{2}\right)$ mitigation, avoidance of critical waste and economic innovation, but can ultimately lead to a higher demand for wood resources.

Alongside reliable environmental assessment of wood products as well as strong legislation and monitoring systems in the respective wood-producing country, new, material-efficient technologies are needed in order to reduce the pressure on forest ecosystems. Being able to use even the short sections of the tree crown and to exploit less critical wood species from the region, molded wood has the potential to substitute conventional wood processing technologies in the construction and furniture sector in the future [7]. Moreover, new areas of application can be opened in the construction sector, which is nowadays mainly characterized by concrete and steel [17], by improving the wood-inherent properties in a way that they gain a high stability, diversity of forms, and resistance to environmental influences.

Strategies, either on the economic or the corporate level, that are based on an increased use of renewable resources such as wood are not environmentally beneficial when resource extraction exceeds the carrying capacity of forest ecosystems [18]. Therefore, an evaluation of the sustainability of wood products is needed, in which the entire product life cycle is considered including the likely affected ecosystems. Environmental indicators can contribute to evaluation of wood products in general and more specifically to an assessment of the site-dependent impacts of a more biobased economy.

In Section 2, theoretical considerations and definitions regarding the sustainable use of forest ecosystems, life cycle thinking, and site-dependent aspects are introduced before the applied scientific methods and materials are presented in Section 3 of this article. The results are shown in Section 4 and further discussed regarding the contained site-dependent aspects and their implementation in corporate decision-making in Section 5. Final remarks and an outlook for future research demand conclude this article.

\section{Theoretical Considerations and Definitions}

\subsection{Existing Criteria and Indicators for the Sustainable Use of Forest Ecosystems}

In connection with forest ecosystems, criteria and indicators are used to conceptualize and implement sustainable forest management (SFM) at the level of nations, regions, or forest management units (FMU), and to facilitate the monitoring of the effectiveness and quality of SFM $[19,20]$. Criteria should always reflect general principles of the sustainable use of forests, e.g., as they are laid out in the documents Agenda 21 and Forest Principles of the United Nations Conference on Environment and Development (UNCED) [20-22]. Furthermore, they should be quantified, qualified, or described by indicators that are measurable, of analytical soundness, and relevant to stakeholders [20,23]. Indicators can be defined as variables meant to describe both the actual state and the development of systems [24]. For instance, Forest Principle No. 15 [22] reads "Pollutants, particularly air-borne pollutants, including those responsible for acidic deposition, that are harmful to the health of forest ecosystems at the local, national, regional and global levels should be controlled." and can be addressed

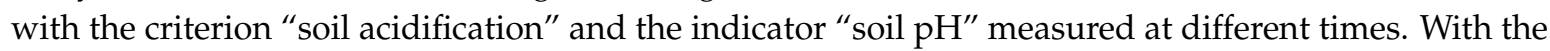


help of indicators, environmental information about complex phenomena can be quantified and simplified to improve communication [25] and support strategic and operational decision-making. The selection of suitable environmental indicators is a process with different decision points and usually dependent on political objectives or scientific requirements and, therefore, requires a high level of transparency about the basis of the information [26].

Because of these requirements, the development of scientifically-sound and internationally agreed upon criteria and indicators has been a long stakeholder process which gathered pace particularly after the United Nations Conference on Environment and Development in 1992 in Rio de Janeiro. Stimulated by the findings of UNCED [21,22] and convinced by their urgency, intergovernmental initiatives around the world have intensified their work on the definition of criteria and indicators for the implementation at regional, national and FMU levels [27]. The European initiative, which was led by the Ministerial Conference on the Protection of Forests in Europe (MCPFE: Helsinki 1993, Lisbon 1998, Vienna 2003), finally resulted in the development of the Improved Pan-European Indicators for Sustainable Forest Management, which were adopted in 2002 [28]. Another simultaneous initiative on boreal and temperate forests in North America was the Montreal Process. The International Tropical Timber Organization (ITTO) already started in 1992 to develop criteria for the monitoring of sustainability in tropical forests. As a result of the different geographical backgrounds of the initiatives, various concepts and an extensive set of criteria and indicators have been produced, which, though they are largely comparable, ask for harmonization [20].

Some international non-governmental organizations, such as Forest Stewardship Council (FSC) [29] and Program for the Endorsement of Forest Certification schemes (PEFC) [30], just to mention the two most prevalent ones [31], have developed different sets of criteria and indicators for the FMU level. Furthermore, they have initiated a voluntary labeling system that allows not only for the certification of forest resources but also the tracking of wood products emerging out of these resources (chain-of-custody certification) [32].

\subsection{Existing Criteria and Indicators from a Life Cycle Perspective}

For a holistic evaluation of wood products, we have to move the focus away from simply the resource to the whole product life cycle. Due to the wide range of possible uses of wood for material and energetic purposes, the generation of manifold by-products, and the possibility of repeated use (wood cascade), the forest wood chain (FWC) is often used as a comprehensive concept [33]. In a forest wood chain, the production and eventual consumption of different primary and secondary wood products is linked to the original forest resource; however, the single processes might be geographically separated due to global transport and trade [34]. Established evaluation techniques that are based on the quantification of material and energy flows along a product's life cycle are life cycle assessment (LCA), material flow analysis (MFA), carbon footprint (CF), or life cycle sustainability assessment (LCSA). Life cycle inventory (LCI) databases such as ecoinvent [35], GaBi [36], or Probas [37] provide quantitative information for a process-based modeling of wood products. In 2007, the developers of the ecoinvent version 2 database [38] issued specific technical background information on how to calculate environmental impacts of the energetic and material use of wood [33]. A total of 100 wood products and wood utilizations have been inventoried in order to identify the most relevant influencing variables on the LCA results of wood. Furthermore, they derived eight criteria for a sustainable use of wood which should be considered in life cycle assessments, e.g., efficient processing and effective use of wood, avoidance of chemical preservatives and careful selection of coating materials, easier recycling, use of incineration residues as fertilizer, and production of durable wood products.

Since Werner et al. (2007) [33] primarily focus on aspects that are methodologically evaluable by life cycle assessments, the authors of this review complemented the list of criteria with principles found in the criteria and indicators schemes of intergovernmental initiatives such as MCPFE [28], non-governmental initiatives such as FSC [29] and PEFC [30], corporate associations such as the World Business Council for Sustainable Development (WBCSD) [39], and additional scientific literature [40]. 
All principles were then summarized to form the following key messages on a sustainable use of wood resources and products over the whole life cycle (see Table 1).

Table 1. Principles for the sustainable use of wood over the whole life cycle (based on $[28-30,33,39,40]$ ).

\begin{tabular}{|c|c|}
\hline Life Cycle Stage & Principle \\
\hline Resource & $\begin{array}{l}\text { Maintaining the health, productivity, protective and recreational functions as well as the } \mathrm{CO}_{2} \text { retention of } \\
\text { forests (ecosystem services) }\end{array}$ \\
\hline Upstream chain & $\begin{array}{l}\text { Careful logging } \\
\text { Priority use of low-value timber } \\
\text { Use of certified wood } \\
\text { Use of many wood species (biodiversity) } \\
\text { Use local wood resources (transport) }\end{array}$ \\
\hline Production & $\begin{array}{l}\text { Production of smaller dimensions } \\
\text { Production of higher added value products (up-scaling) } \\
\text { Reduction of waste (material efficiency) } \\
\text { Use of minimally processed wood } \\
\text { Production of durable wood products } \\
\text { Ensuring the decomposition into preferably unmixed fractions (eco-design) }\end{array}$ \\
\hline Use & $\begin{array}{l}\text { Low use of impregnating agents in dependence of the application situation } \\
\text { Priority use of natural or low toxic coatings } \\
\text { Higher service intensity of goods and services }\end{array}$ \\
\hline End of life & $\begin{array}{l}\text { Wood utilization longer than growth cycle of timber of comparable size and quality (carbon storage) } \\
\text { Use of recycled wood (wood cascade) } \\
\text { Use of combustion residues as fertilizer (cradle-to-cradle) }\end{array}$ \\
\hline
\end{tabular}

Some researchers have already established life cycle thinking in the evaluation of single wood products or complete forest wood chains and have selected indicator sets for each life cycle stage following more or less the principles shown in Table 1. Because there is no standard practice, the selection, prioritization, and grouping of indicators was determined by overall objectives and mindsets of the researchers, or causal relationships.

Geibler et al. (2010) [41] developed their indicator set by analyzing the concepts of different sustainability initiatives along the forest value chain, splitting the concepts into dimensions, categories, aspects, and indicators, and validating the selection outcome within a stakeholder process. Cobut et al. (2012) [42] investigated environmental indicators in a life cycle perspective by comparing different ISO (International Organization for Standardization) type I ecolabels in North America, Europe, and Japan. Lindner et al. (2010) [34] used similar existing indicator sets to develop a sustainability indicator framework for the whole FWC, which enables not only a balanced consideration of the three dimensions of sustainability, but also the use of qualitative indicators and whole-chain as well as chain segment related indicators. With the final assessment tool ToSIA (Tool for Sustainability Impact Assessments of forest-wood-chains), they were then able to compare different FWC technologies, political measures, or a changed consumer behavior [43].

None of these authors derived their indicator sets and methodological approaches from a systematic literature search or examined possibilities to consider site-dependent aspects in holistic sustainability analyses. For the practical demonstration of their conceptual frameworks, only a few indicators have been utilized. Which position an indicator holds in a cause-and-effect relationship is not explicitly mentioned, nor are indicators set in relation to existing causal chain concepts.

One common causal approach we applied in this study to classify indicators is the Pressure-State-Response (PSR) framework. It was originally developed by the Organization for Economic Co-operation and Development (OECD) and examines human activities in relation to impacts on the environment and eventual feedback from society [23,44]. It distinguishes three indicator categories: indicators of environmental conditions (state of natural resources), indicators of environmental pressures (pressure by human activities), and response indicators (societal response). Although this causal chain concept is recommended from a scientific point of view, it is rather used for the presentation of indicator results than for their selection [45]. The framework has already been 
extended by the European Environment Agency to the Driving force-Pressure-State-Impact-Response (DPSIR) framework to better address the individual contributions of different economies to current and future environmental problems (driving forces) and to develop sector-specific measures (response) [46]. However, we chose the simplified PSR concept because, based on the given information in the sample, the collected indicators could not be unequivocally allocated to a particular driving force or response in the sense of the DPSIR concept. Moreover, we see advantages in the use of the PSR concept on the grounds of a better comprehensibility and our focus on the environmental dimension of sustainability [47]. As with the DPSIR structure, the PSR structure is also compatible with the cause-effect logic in corporate decision-making [48,49].

\subsection{Site-Dependent Aspects}

Forest ecosystems are affected by many stress factors. Fragmentation by infrastructure, invasive species, and climate change can have severe influences depending on the inherent vulnerability of forests [50]. The use of wood resources should therefore consider the current status of forest ecosystems and possible pre-existing defects.

On a local scale, assessments of the drivers of vulnerability of forests, e.g., climate change, forest land-use change, forest management, or the use of forests by the community, are, according to Sharma et al. (2013) [51], not available or adequate methods are missing in order to establish appropriate forest management schemes. The prevailing method for ecological wood product assessments from a life cycle perspective including the consideration of upstream chains is life cycle assessment, as is later shown within this review. However, most LCAs only focus on the production part of a product life cycle without taking the environmental impacts of biological production systems into account [52]. Moreover, forest ecosystems and wood industries are dynamic systems in the dimensions of time and space [52], a fact that cannot be addressed with static models representing an abstract environment only. Hofstetter (1998) [53] describes this drawback of LCAs in a triple-sphere concept (valuesphere, ecosphere, and technosphere) and calls for a differentiated assessment of site-specific aspects in order to better understand the interactions between a product system (technosphere) and its surrounding environment (ecosphere). Besides this, he explains the regional dependency of the valuesphere of human beings with the help of cultural theory. The valuesphere encompasses human beliefs, attitudes, and convictions and leads to subjective choices of LCA analysts and decision makers, e.g., while defining the goal and scope or selecting safeguard objects (health, resources, and nature) [53].

An analysis utilizing geographic information systems (GIS) poses an alternative streamlined approach to characterize the vulnerability of forest ecosystems instead of a cost-intensive on-site risk assessment [54]. The challenge is then to find georeferenced data at a good quality and appropriate spatial resolution that allow the deduction of sound environmental indicator values and the drawing of an accurate picture of the status of a forest ecosystem. Moreover, in corporate decision-making on products and raw materials, the use of georeferenced data is not yet the state of the art as it is in landscape, resource and infrastructure planning [55-57].

\subsection{Overall Objectives of the Review}

The present study is motivated by a holistic perspective on the environmental impacts of wood products. Therefore, criteria and indicators to evaluate their sustainability should be systematically identified in the scientific literature. This search should start without any methodological restrictions in the beginning to find approaches beyond LCA. The study focuses on the environmental dimension of sustainability only and thus takes a closer look at the processes at the boundary between the technosphere and ecosphere, following the concept of Hofstetter (1998) [53]. Nevertheless, technical and social aspects are likewise considered when they are closely related to environmental aspects, as the distinction between them can be fuzzy. Moreover, the life cycle of wood products in a classical sense of LCA should be considered as well as possible site-dependent aspects. The study does not 
distinguish between wood resources from natural systems (natural forests) and wood resources from human-made systems (silviculture) [58].

Based on the deliberations above, two main questions were of particular interest to the authors when conducting the study:

- Which environmental indicators and scientific methods exist in the literature for a life cycle oriented, ecosystem-based assessment of wood products?

- Which site-dependent aspects are involved in the environmental assessment of wood products?

The following section describes the step-by-step procedure of the systematic literature review and the materials we chose to answer the research questions.

\section{Materials and Methods}

A systematic literature review can deliver a reliable and evidence-based knowledge basis for a specific phenomenon or question and, therefore, supports well-informed and context-sensitive decisions of practitioners and policy-makers [59]. As a transparent and reproducible method, it also raises the methodological rigor of academic research [59]. Based on the advantages for all stakeholder groups, we chose a systematic literature review for this study to answer the research questions on sustainable wood products explicitly and comprehensively [60]. For the search and screening process of the literature and the selection of appropriate exclusion and inclusion criteria, respectively, we followed the recommendations of Fink (2014) [60], Littell et al. (2008) [61], and Zumsteg et al. (2012) [62].

In a first step, we used our research questions derived in the second section of this article to obtain appropriate search terms. Furthermore, we identified suitable literature databases and websites and discussed all choices within a group of researchers specialized in environmental evaluations and systematic literature reviews. The final literature search was conducted in February 2016 by means of two bibliographic databases (EBSCOhost-Academic Search Complete and Business Source Complete, Web of Science) and the online search engines of four major publishers (ScienceDirect, Emerald, SpringerLink, and Wiley). For unpublished work and conference proceedings, we used Google Scholar and SSRN (Social Science Research Network). In all search cases, Boolean operators were used, allowing for the connection of four search terms and the consideration of synonyms for "wood", "environmental", "indicator", and "life cycle", so that not only comprehensive but also specific search results could be obtained (see Table 2 and Table S1). By including the term "forest", the search is extended to the forest ecosystem in order to respect the linkage between the product system and the natural resource. As the study put emphasis on the ecological dimension of sustainability, the economic and social dimensions were not directly sought with the selected search terms, which should not diminish their principal importance. Nevertheless, the terms "sustainab" and "green" have been included in order to not exclude information from studies focusing on the broader concept of sustainability.

Table 2. Search terms.

\begin{tabular}{|c|c|c|c|c|c|c|}
\hline Term 1 & & Term 2 & & Term 3 & & Term 4 \\
\hline $\begin{array}{c}\text { wood } \\
\text { timber } \\
\text { forest }\end{array}$ & AND & $\begin{array}{c}\text { environmental } \\
\text { ecological } \\
\text { sustainab }^{*} \\
\text { green }\end{array}$ & AND & $\begin{array}{c}\text { indicator } \\
\text { criteria } \\
\text { index }\end{array}$ & AND & $\begin{array}{c}\text { life cycle } \\
\text { life-cycle } \\
\text { chain }\end{array}$ \\
\hline
\end{tabular}

* The asterisk serves as wildcard to find all terms sharing the same word root.

The respective search algorithm was primarily applied to title, abstract, and keywords, whereas the SpringerLink search engine only delivered results within a full text search. A total of 1717 hits, of which 1280 hits were without duplicates, could be obtained with this search routine including peer-reviewed articles, books, research reports, and conference proceedings (see Figure 1). 


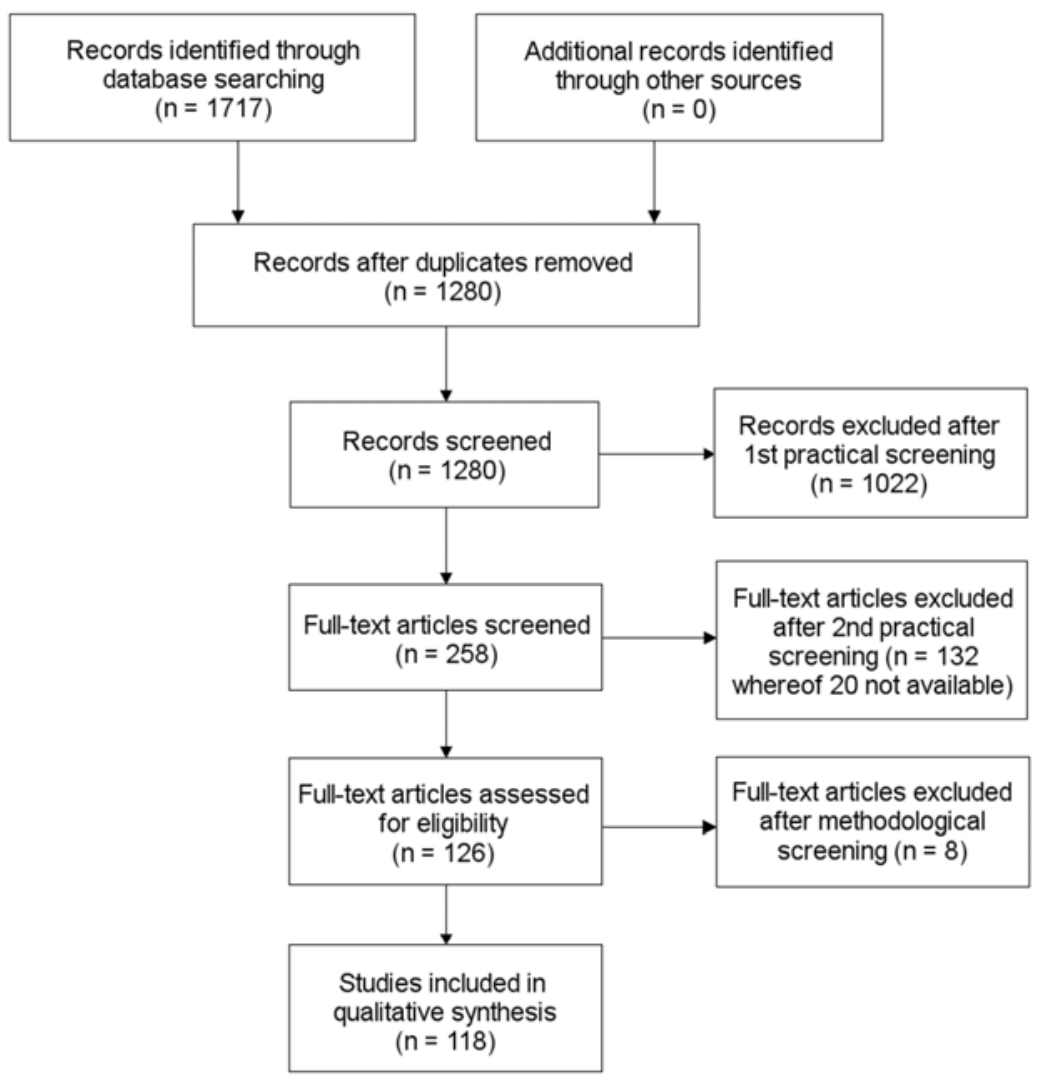

Figure 1. Stepwise process chart for the systematic literature review (based on [63]).

In a second step, practical screening criteria have been applied to the search results by reading the title, abstract, and keywords of the publications. No restrictions were specified with regard to the time frame the publication was issued. All publications written in English language were considered independently from their cultural and geographic background. Literature with no direct access to the original source was excluded. Based on our research questions and the overall objective of the review, which is primarily the assessment of wood products, literature on bioplastics, bioenergy, pulp and paper, as well as short rotation coppice was ignored. The scope was further narrowed to literature that use indicators or specific criteria to evaluate the wood product's sustainability, as we were specifically interested in the use of the indicators for decision-making purposes, and to literature that considers at least one phase of a wood product's life cycle. The review should focus on diverse indicator-based methods applied similarly in research and practice; however, the authors were aware that the literature search might lead to a sample that is biased in a way that it is dominated by quantitative studies [61] such as life cycle assessments and underrepresented by unpublished studies [64], e.g., studies from practice. Qualitative studies investigating and developing scientific concepts around the topic were fully considered by the review and only serious quality deficiencies in the eyes of the authors of this review should lead to the exclusion of a study. Consequently, 1022 non-relevant publications were excluded from further study.

It was decided that a second practical screening should be run on the full text of the remaining 258 publications in order to assure a consistent input sample for the methodological screening, as this should be conducted as part of the final content analysis. In this way, 112 publications could be excluded due to their content irrelevance and 20 due to their non-availability, a rejection rate that is considered tolerable with respect to the remaining sample size of 126 publications. A further eight publications were later recognized as being irrelevant for the research questions during the methodological screening of the full text. 
In a fourth step, the textual content of 118 publications (see Table S2 for a detailed list of reviewed publications) was analyzed with the support of the MAXQDA coding software [65], among them being 114 peer-reviewed studies, one report, and three book chapters. Qualitative content analysis was the method of choice for the synthesis of the search results as it helps to structure large datasets in a systematic and verifiable way $[66,67]$. The development of the coding scheme and the reading of the publications was guided by the overarching research questions embedded in the PSR framework. This approach avoids abstract categorizations, facilitates and accelerates the sampling of relevant text, and helps to draw correct inferences from the written text to answer the research questions [66]. Furthermore, it makes clear which context in terms of the assumed network of correlations the authors chose for the content analysis [66].

The coding scheme should not only reflect the research questions appropriately, its category codes should also be exhaustive, explicit, and independent from each other [68]. Meeting these requirements, seven independent category codes (bibliography, study details, research approach, indicators, origin of indicators, region-specific aspects, and other) were defined by the authors prior to the actual coding process. Furthermore, first subcodes were determined based on common classifications in life cycle assessments [69], decision-making principles, and stakeholder theory [70] (see Table 3). During the reading of the selected literature, the coding scheme was complemented with additional subcodes inductively derived from texts so that the final coding scheme encompassed 291 subcodes (see Table S3 for the complete coding scheme).

Table 3. Coding scheme: Category codes and 1st level subcodes.

\begin{tabular}{|c|c|c|c|c|c|c|}
\hline Bibliography & Study Details & $\begin{array}{l}\text { Research } \\
\text { Approach }\end{array}$ & Indicators & Origin of Indicators & $\begin{array}{l}\text { Region-Specific } \\
\text { Aspects }\end{array}$ & Others \\
\hline Title & Main topic & \multirow{6}{*}{$\begin{array}{l}\text { Study design } \\
\text { Methods }\end{array}$} & & Policy & \multirow{6}{*}{$\begin{array}{c}\text { Ecosystem } \\
\text { Methodology } \\
\text { Social perspective }\end{array}$} & \multirow{6}{*}{$\begin{array}{l}\text { Results } \\
\text { Further } \\
\text { research } \\
\text { demand }\end{array}$} \\
\hline Author & Region & & & Policy-Science & & \\
\hline Year & Continent & & Pressure & Science & & \\
\hline Journal, & Sector & & State & Science-Industry & & \\
\hline publisher & Life cycle & & & Industry & & \\
\hline Funding & Wood resource & & & Policy-Science-Industry & & \\
\hline
\end{tabular}

The first author completed the first round of coding, and then reviewed the codings a second time (intra-coder reliability) to increase their objectivity and reliability $[66,67]$. The material-oriented validity was met by a systematic sampling procedure and a joint verification of the coding scheme and categories in conjunction with the co-authors [66,68]. Further measures ensuring a high quality of the review include a comprehensive documentation (see Tables S1 and S4) and a fully computer-aided analysis. For the interpretation of the results, there is a distinction between the number of documents $\left(\mathrm{N}_{\mathrm{doc}}\right)$ and the number of codings $\left(\mathrm{N}_{\mathrm{cod}}\right)$, which can differ from each other due to multiple coded attributes.

\section{Results}

\subsection{Characterization of the Sample}

The sample $\left(\mathrm{N}_{\mathrm{doc}}=118\right)$ is characterized by a high number of case studies $(70 \%)$. Conceptual work can be found only in one third of the studies (see Figure 2). Most of the authors focus on Europe as their area of investigation, which correlates with the high number of main authors $(72 \%)$ reporting European backgrounds. In total, only 33 countries are represented by the sample. The oldest publication in the sample is an article from Davidson (1985) [71] concerning the consequences of exploiting the resources of tropical forests published in The Environmentalist. The most frequently used journal for publication is the International Journal of Life Cycle Assessment since LCA and footprints are the most relevant methods applied in the studies. Other common journals are the European Journal of Forest Research and the Journal of Cleaner Production. 


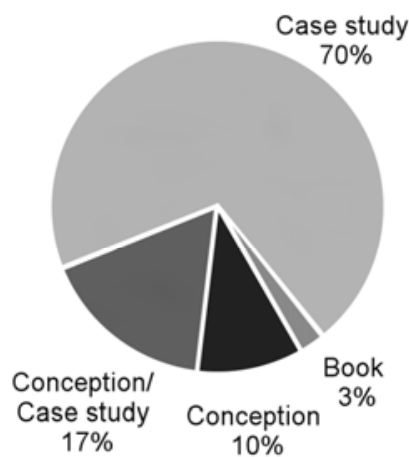

(a)

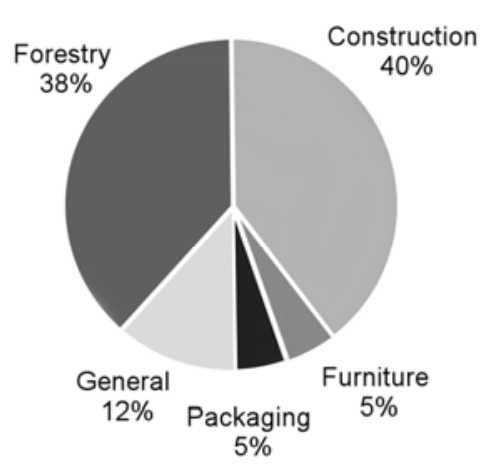

(b)

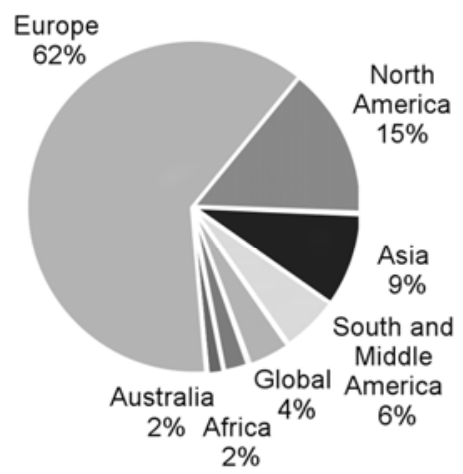

(c)

Figure 2. Characteristics of the sample: (a) Study design $\left(\mathrm{N}_{\mathrm{cod}}=118, \mathrm{~N}_{\mathrm{doc}}=118\right)$; (b) Sectors $\left(\mathrm{N}_{\mathrm{cod}}=118, \mathrm{~N}_{\mathrm{doc}}=118\right)$; and (c) Study region $\left(\mathrm{N}_{\mathrm{cod}}=122, \mathrm{~N}_{\mathrm{doc}}=118\right)$.

To discover possible external influences on the study execution and research results, all funding sources mentioned in the acknowledgements of the studies have been coded. It turned out that the prevailing form of funding was national funding (39\%). Funding from the European Union (EU) (10\%) or from the United Nations (UN) (1\%) are rather underrepresented in the sample. Furthermore, it can be shown that some studies from universities (19\%) were financed by their own resources that are not further specified or were a result of a doctoral dissertation. At least $19 \%$ of the studies obtained support from industry either by direct financing or by provision of data and expertise, and $12 \%$ of the studies from non-governmental organizations.

The majority of studies deal with environmental issues within the construction $\left(\mathrm{N}_{\mathrm{doc}}=47\right)$ and forestry sector $\left(\mathrm{N}_{\mathrm{doc}}=45\right)$. A few studies address the furniture $\left(\mathrm{N}_{\mathrm{doc}}=6\right)$ and packaging sector $\left(\mathrm{N}_{\mathrm{doc}}=6\right)$. Fourteen studies tackle more general, superordinate aspects such as wood transport, forest wood chains (partly or as a whole), total organic carbon flows including carbon sequestration and the cascading use of wood.

Because the sample was overrepresented by European studies, softwood species such as pine $\left(\mathrm{N}_{\mathrm{doc}}=29\right)$ and spruce $\left(\mathrm{N}_{\mathrm{doc}}=15\right)$ were the most investigated tree species followed by endemic hardwood species such as beech $\left(\mathrm{N}_{\mathrm{doc}}=13\right)$ and oak $\left(\mathrm{N}_{\mathrm{doc}}=7\right)$.

The prevailing methodology among all studies is LCA. Taking also LCI, LCSA, and footprints into account, it appeared 78 times $(66 \%)$ in the sample. Due to the selected research questions and search terms, this result is not surprising. Rather interesting is the fact that in $51 \%$ of all studies the study authors combined at least two methodologies to broaden their investigation. With the help of the functions Configuration Table and Code-Co-Occurrence Model within MAXQDA (see Figure 3), the most common combination pairs could be identified: LCA + numerical modeling [72-82], LCA + eco-design concept [75,76,83-91], LCA + Multi Criteria Decision Analysis (MCDA) [79,92-95], and MCDA + Criteria and Indicators $[41,44,50,96,97]$. Although statistical analyses such as regression analysis, correlation analysis, and cluster analysis are strong tools for the evaluation of empirical data, they were not frequently used throughout the sample.

All investigated wood objects mentioned in the studies were grouped according to the associated sector and then juxtaposed with their particular reference objects. Reference objects are alternative investigation objects (e.g., different scenarios) the wooden investigation object is directly compared with. They were grouped according to the life cycle stages addressed in the studies or assigned to methodological aspects. By counting the occurrence of the different combinations, the main research fields of the sample of this review could be identified (see Figure 4 and Table S2). 


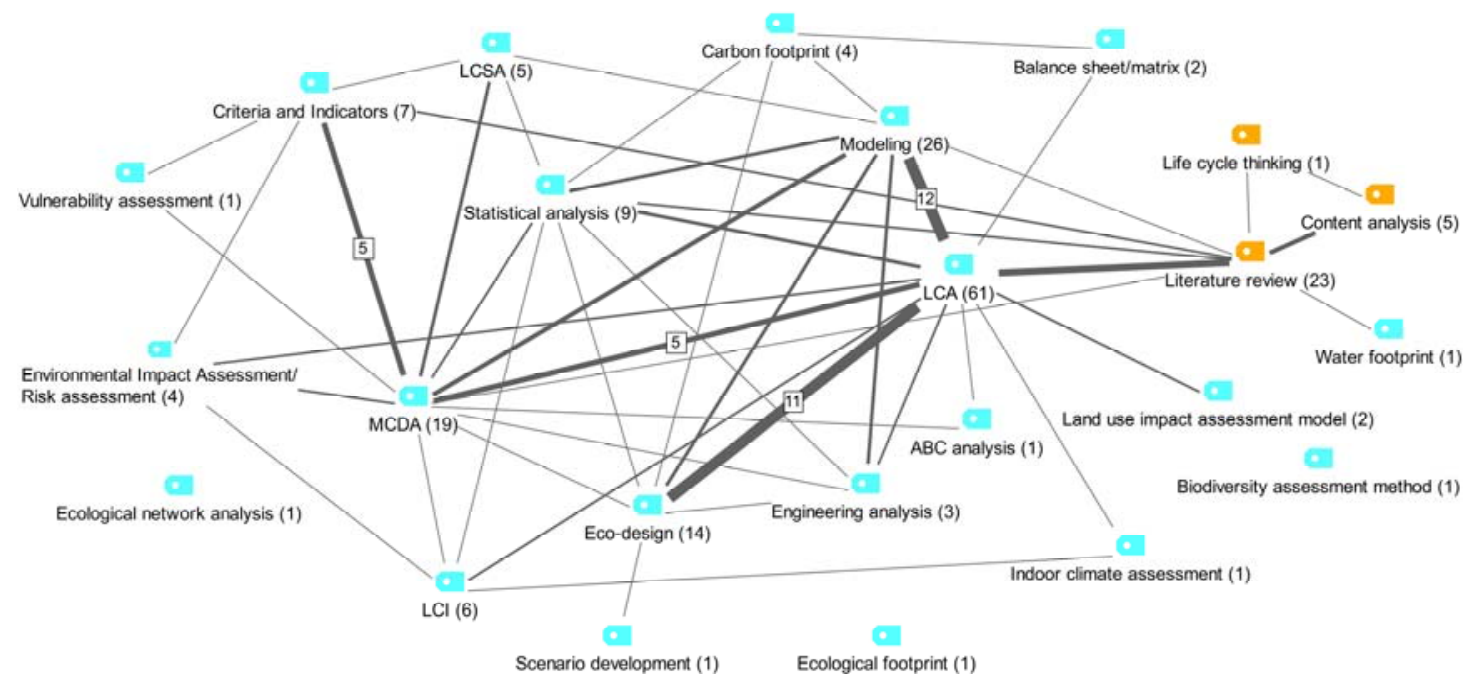

Figure 3. Usage of scientific methods in the sample. The frequency of occurrence is shown in brackets after the indicated method and for the most common combinations of methods along the connection lines. Methods shown in orange color do not contribute to the methodological extension of methods shown in blue color, but were kept in the figure for the sake of completeness.

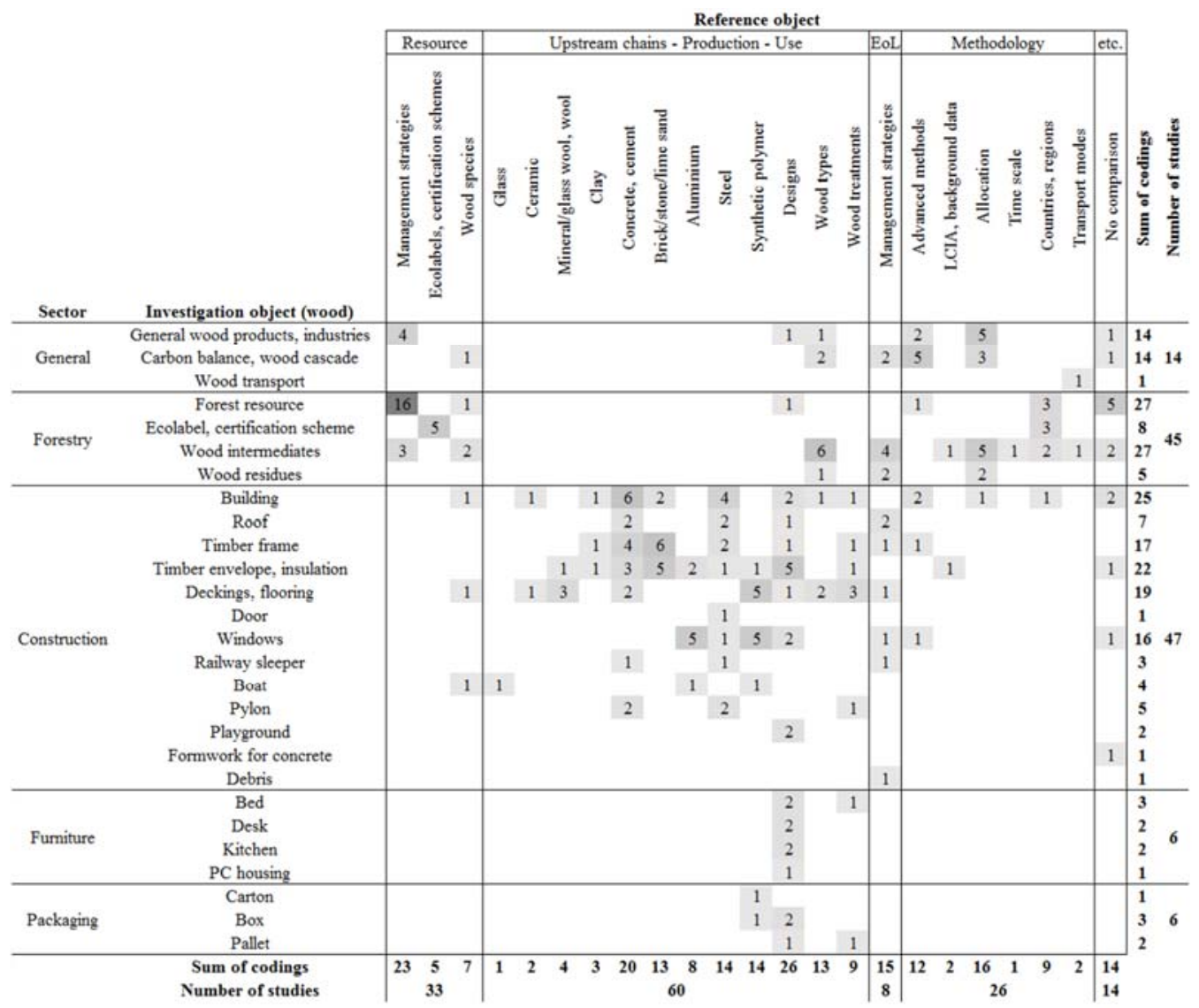

Figure 4. Main research fields of the sample determined by the frequency of different combinations of wooden investigation objects $\left(\mathrm{N}_{\mathrm{cod}}=233, \mathrm{~N}_{\mathrm{doc}}=118\right)$ and their reference objects $\left(\mathrm{N}_{\mathrm{cod}}=233\right.$, $\mathrm{N}_{\mathrm{doc}}=141$ ). Multiple options are possible and thus lead to a higher number of codings than studies.

Forestry-related studies have set their focus in most cases on a comparison of different forest management strategies [98-105] or specific ecolabels and certification schemes such as FSC and 
PEFC [11,106-109] in different geographical regions. FWCs are sometimes only partly covered by studies comprising the processes from harvest to the sawmill gate [110], or from harvest to intermediate wood products leaving the sawmill gate (e.g., sawn wood and by-products) [111], or further on to the end consumer wood product leaving the factory gate as an engineered wood product (e.g., plywood, particle boards, fiber boards, laminates, or veneers). In those cases, the impacts of different wood types, end-of-life strategies, or effects of different allocation strategies were usually explored $[83,112,113]$.

FWCs are considered as a whole in order to define and test holistic sustainability indicators or to investigate the influence of changed forest management regimes [34,41,96]. For the investigation of the influence of the wood products industry on the global carbon balance and the potential of carbon sequestration through an increased use of wood products, dynamic optimization models have been applied by some authors [114-117]. Different transport modes for wood were addressed by only two studies [118,119].

In particular, some LCA studies investigate the effectiveness of advanced methodological approaches, for instance the integration of biodiversity or land use assessment methods into LCA [120,121], or different allocation schemes in case of multi-output processes [43,74,122]. Furthermore, the sensitivity of results has been tested by a variation of LCIA methods [78], background processes such as energy supply systems [119], the time horizon [123], or the geographical reference system [124,125].

Construction-related studies primarily examine the whole building or single building components and compare the wood case with other construction materials such as concrete, brick, stone, steel, aluminum, and synthetic polymers [126-133]. The comparison of different wood treatments, e.g., by means of copper, zinc, boron, or chromium [95,134,135], or different designs $[85,92,136]$ represents a central research approach in some studies. Only a few studies address furniture or packaging items. For the sake of simplicity, one study [137] was allocated to furniture though the object under investigation rather belongs to household devices. A total of 14 studies do not follow a comparative approach [50,52,82,138-148].

\subsection{Collected Indicators}

The main objective of the presented study was a collection of indicators for wood products that allow for the evaluation of their environmental dimension of sustainability over the entire life cycle. In order to provide a first structured overview of the identified indicators, general headings were assigned to them according to Pressure-State-Response framework (see Figure 5). Altogether, 700 codings were set in the documents, more than half of them belonging to the large canon of impact category-indicators of classical LCIA. As these indicators are used to describe the environmental burden of industrial products, they are categorized as anthropogenic Pressure exerted during the wood product life cycle on the natural environment. Most of the studies apply midpoint indicators to their investigated object $[75,112,149]$. If applied, category endpoints are mainly used to evaluate the damage to the natural environment [92,107] or the loss of natural resources [81,113]. In some comparative studies $[83,121,138]$, the application of single score indicators such as Eco-indicator 95/99 [150], ReCiPe [151], or IMPACT 2002+ [152] was the method of choice to facilitate the assessment of alternatives. Another common group of indicators we have allocated to Pressure are LCI indicators representing the elementary input and output flows of material or energy entering and leaving the system without human transformation [69]. Those could be collected from, e.g., [8,121,153]. 


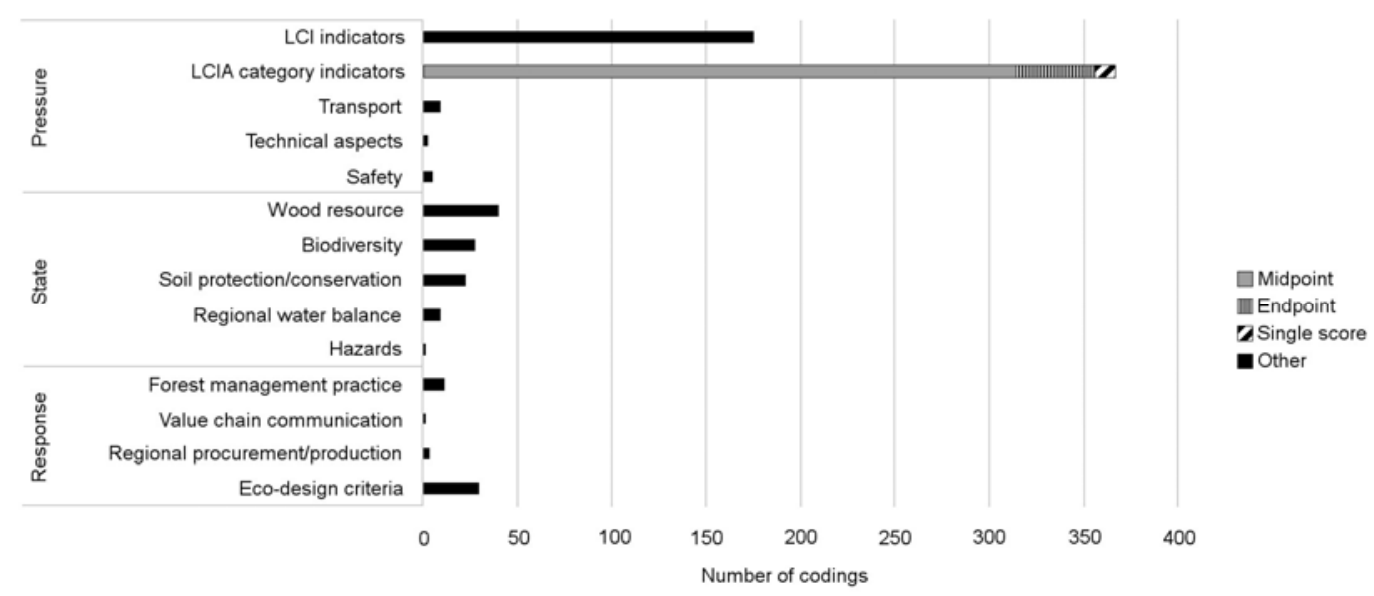

Figure 5. Number of codings in different indicator groups $\left(\mathrm{N}_{\mathrm{cod}}=700, \mathrm{~N}_{\mathrm{doc}}=118\right)$.

Concerning the State of the ecosystem that is impacted by the pressures, we found several indicators describing the wood resource itself, e.g., as area covered by forest $[98,103,105,108]$, as standing volume [100,136] and carbon stock [80,145], as proportion of dead wood [120], tree height [105], or tree age [120]. To meet the complex nature of biodiversity, some authors helped themselves by quantifying the genetic diversity or the invasive species in a particular area $[50,72,107]$ or by using the size of areas under protection as a proxy indicator [44,154]. The matter of soil protection was addressed by some studies with the determination of the soil fertility [96], the soil erosion potential [139], pedochemical parameters such as cation exchange capacity [71,72], or the $\mathrm{pH}$ value [120]; however, the actual procedure for the determination of the indicators often remained vague in the studies. The regional water balance was investigated by some studies by measuring the precipitation [155], evapotranspiration or surface runoff in a certain area [72], or by modeling the whole water flow in the water catchment area $[52,100]$. The frequency and spatial extent of hazards such as fire incidents [50] can have a severe impact on the State of a forest ecosystem and was therefore included in the list of codings.

Indicators describing the forest management practice in terms of legality, logging, and reforestation $[104,111,141,156]$ represent decision-making both on a strategic and operational level. They are assigned to the category Response as the introduction of forest management rules is considered a consequence of former mismanagement. Regional wood production has advantages in terms of short transport distances and local added value. It is determined by some studies as production within a specific radius [76] or as a ratio of regionally produced wood to the total wood used [41]. Since the decision on the use of a regional resource should be made depending on the state of the resource itself, this indicator is interpreted as a Response. Value chain communication refers to the active involvement of actors along the steps of the value chain such as suppliers and results from a learning process about the optimization of wood products [41]. Similarly, eco-design principles such as the use of recycled wood or certified wood, the application of modular concepts, or the avoidance of critical materials emerge from critical mindsets of humans and thus are allocated to the category Response [85,89].

We further characterized the indicators regarding their origin by differentiating between three stakeholder groups (policy, science, and industry) [70]. In total, we found 57 indicator sources in the studies. The background information about the authorship was either directly extracted from the studies or determined by follow-up research. In $54 \%$ of all cases, the policy was either involved together with other stakeholders in the development of the respective indicator or the sole driver. Science and industry were involved in $54 \%$ and $40 \%$ of all cases, respectively. This can be considered an almost balanced ratio among all stakeholders, which also reflects their principle interests in this issue. A full list of the origins of indicators is provided in Table A1. 


\section{Discussion}

\subsection{Identified Indicators from a Life Cycle Perspective}

The arrangement of all collected indicators along the life cycle of a wood product exhibits obvious gaps especially for the ecosphere (see Table 4). This is owed to the fact that the coded indicators have been used in the studies only to describe the State of the wood resource, i.e., the forest ecosystem. They were not used to evaluate other affected ecosystems along the life cycle of a wood product. As the value chain of a wood product is a global issue nowadays, the integration of the spatial dimension of environmental impacts (Pressure) in environmental assessments is necessary to obtain a more realistic picture. This can be accomplished with the support of GIS tools. A special position is taken by category indicators from life cycle assessments as they cumulate all environmental impacts over the life cycle or only parts of it depending on the chosen system boundaries. The category Response includes principles seen in performance measurement systems, e.g., eco-design principles. By applying those principles, all life cycle stages of a wood product can be addressed.

The allocation of indicators and their level of abstraction, i.e., the specification of an indicator as measureable parameter or as superordinate term without a unit, are not consistent throughout the whole sample of the review. Moreover, we see many blank fields. This is due to the different mindsets and objectives of the respective researchers. Precise indicators and metrics are not always available for each aspect and a clear differentiation between aspects and indicators is often missing, which is why we decided not to follow the aspect/indicator differentiating approach of Geibler et al. [41] and to consider 78 indicators in general that could be collected from the given sample.

Table 4. Coded indicators according to the PSR framework and along the wood product's life cycle $\left(\mathrm{N}_{\mathrm{cod}}=700, \mathrm{~N}_{\mathrm{doc}}=118\right)$.

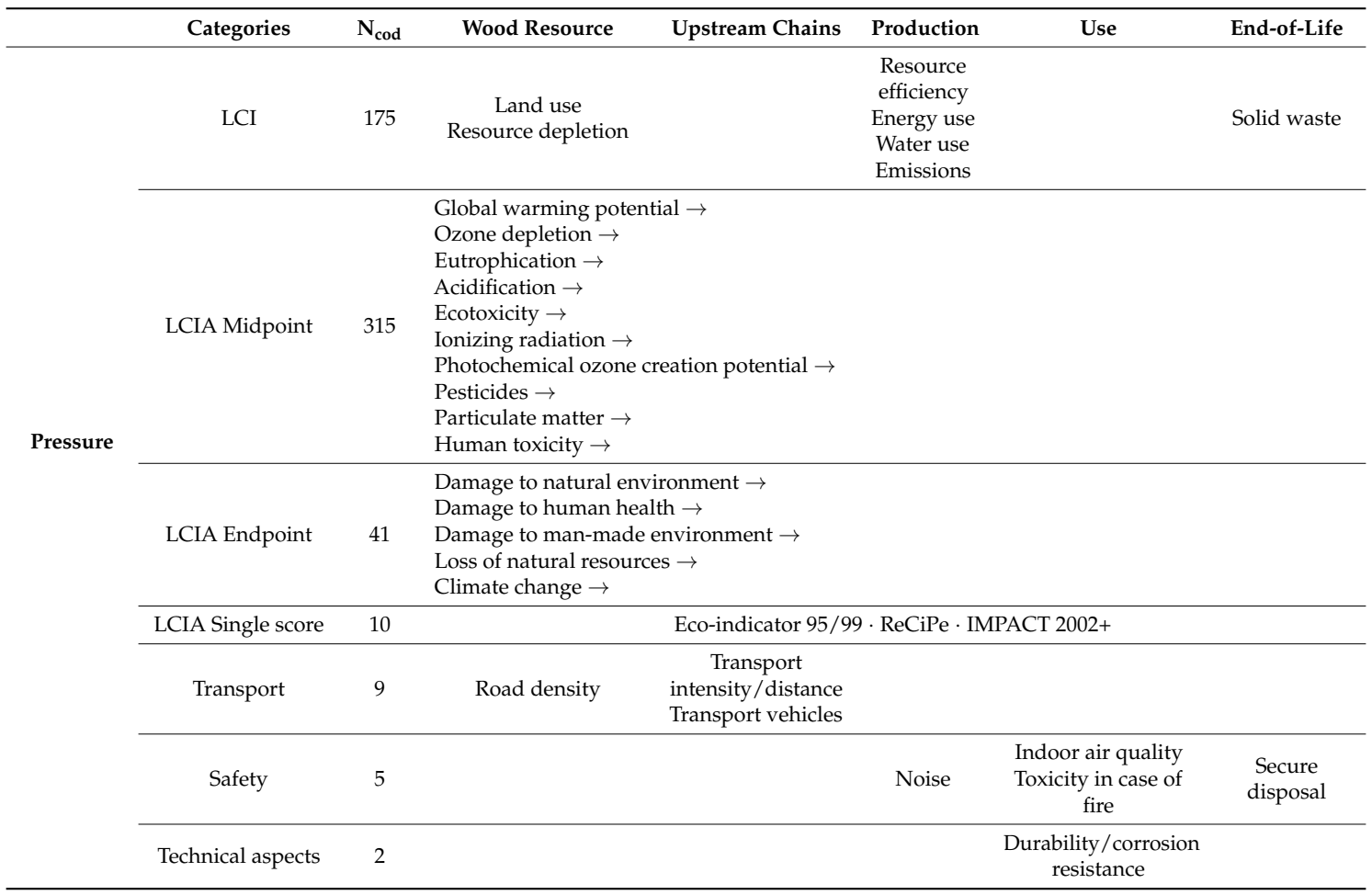


Table 4. Cont.

\begin{tabular}{|c|c|c|c|c|c|c|c|}
\hline & Categories & $\mathbf{N}_{\text {cod }}$ & Wood Resource & Upstream Chains & Production & Use & End-of-Life \\
\hline \multirow{5}{*}{ State } & Wood resource & 40 & $\begin{array}{c}\text { Forest cover } \\
\text { Standing volume } \\
\text { Carbon stock } \\
\text { Tree age } \\
\text { Tree height } \\
\text { Dead wood }\end{array}$ & & & & \\
\hline & Biodiversity & 27 & $\begin{array}{c}\text { Areas under } \\
\text { protection } \\
\text { Number of } \\
\text { animals/plants } \\
\text { Genetic diversity } \\
\text { Rarity of species } \\
\text { Invasive species }\end{array}$ & & & & \\
\hline & $\begin{array}{l}\text { Soil protection/ } \\
\text { conservation }\end{array}$ & 22 & $\begin{array}{c}\text { General soil } \\
\text { protection } \\
\text { N flux } \\
\text { Soil fertility } \\
\text { Soil erosion } \\
\text { Soil compaction } \\
\text { Soil clogging } \\
\text { Cation Exchange } \\
\text { Capacity } \\
\text { Base Saturation } \\
\text { Soil pH } \\
\text { Soil structure } \\
\text { disturbance }\end{array}$ & & & & \\
\hline & $\begin{array}{c}\text { Regional water } \\
\text { balance }\end{array}$ & 9 & $\begin{array}{c}\text { General water } \\
\text { protection } \\
\text { Water quality } \\
\text { Stream flow/water } \\
\text { flux/water balance } \\
\text { Precipitation } \\
\text { Surface runoff } \\
\text { Evapotranspiration }\end{array}$ & & & & \\
\hline & Hazards & 1 & Occurrence of fire & & & & \\
\hline \multirow[t]{4}{*}{ Response } & $\begin{array}{l}\text { Eco design } \\
\text { principles }\end{array}$ & 29 & Certified wood & $\begin{array}{l}\text { Short supply } \\
\text { chains } \\
\text { Environmentally } \\
\text { benign transport }\end{array}$ & $\begin{array}{l}\text { Modular } \\
\text { concept } \\
\text { User-specific } \\
\text { design } \\
\text { Use of } \\
\text { renewable } \\
\text { energy } \\
\text { Avoidance } \\
\text { of critical } \\
\text { materials } \\
\text { Minimal } \\
\text { number of } \\
\text { components }\end{array}$ & Multi-functionality & $\begin{array}{l}\text { Recycling } \\
\text { rate } \\
\text { Reparability } \\
\text { Content } \\
\text { information }\end{array}$ \\
\hline & $\begin{array}{c}\text { Forest } \\
\text { management } \\
\text { practice }\end{array}$ & 11 & $\begin{array}{c}\text { Legality } \\
\text { Logging } \\
\text { Reforestation }\end{array}$ & & & & \\
\hline & $\begin{array}{c}\text { Regional } \\
\text { procurement/-proc }\end{array}$ & ction & $\begin{array}{l}\text { Regional wood } \\
\text { production }\end{array}$ & & & & \\
\hline & $\begin{array}{l}\text { Value chain } \\
\text { communication }\end{array}$ & 1 & & $\begin{array}{l}\text { Sustainability } \\
\text { requirements for } \\
\text { suppliers }\end{array}$ & & & \\
\hline
\end{tabular}

$\rightarrow$ The arrow indicates environmental impacts that can be determined for single life cycle phases or cumulated for the whole life cycle.

\subsection{Site-Dependent Aspects}

The second research question of this study refers to site-dependent aspects and how they are addressed by the different scientific approaches which we collated with the help of this literature review. Site-dependent aspects are first of all strongly associated with the characteristics of ecosystems at small or medium scales depending on the uniformity of their extent. Spatial changes of the characteristics of ecosystems such as land use, water balance, carbon stock, or biodiversity are decisive and measurable parameters for the evaluation of ecosystem functions and vulnerability potentials. However, based on the content of all codings, we distinguish between three categories: site-dependent aspects connected 
with the social perspective of sustainability (1-3); with the environmental perspective of sustainability, specifically the ecosystem (4-9); and with the scientific methodology (10-20) (see Table 5).

Table 5. Inductively derived classification of site-dependent aspects according to the social perspective, characteristics of ecosystems and methodological issues.

\begin{tabular}{|c|c|c|c|c|c|}
\hline No & Site-Dependent Aspect & Social Perspective & Ecosystem & Methodology & Codings $\left(\mathrm{N}_{\mathrm{doc}}\right)$ \\
\hline 1 & Acceptance & $\mathrm{x}$ & & & 4 \\
\hline 2 & National legislation & $\mathrm{x}$ & & & 2 \\
\hline 3 & Country-specific certification schemes & $\mathrm{x}$ & $(\mathrm{x})$ & & 2 \\
\hline 4 & Regional forest inventory data & & $x$ & & 5 \\
\hline 5 & Wood characteristics & & $\mathrm{x}$ & $(\mathrm{x})$ & 3 \\
\hline 6 & Land use & & $\mathrm{x}$ & & 8 \\
\hline 7 & Biodiversity & & $\mathrm{x}$ & & 3 \\
\hline 8 & Water & & $\mathrm{x}$ & & 1 \\
\hline 9 & Climate & & $\mathrm{x}$ & & 2 \\
\hline 10 & Sample selection & & & $\mathrm{x}$ & 5 \\
\hline 11 & Combined methods & & & $x$ & 8 \\
\hline 12 & Country-specific tools & & & $\mathrm{x}$ & 4 \\
\hline 13 & Global value chains & & & $\mathrm{x}$ & 2 \\
\hline 14 & Country-specific databases & & & $\mathrm{x}$ & 23 \\
\hline 15 & Regional damage characterization factors & & $(\mathrm{x})$ & $\mathrm{x}$ & 5 \\
\hline 16 & Scale & $(\mathrm{x})$ & $(\mathrm{x})$ & $\mathrm{x}$ & 8 \\
\hline 17 & Spatiotemporal dynamics & & (x) & $\mathrm{x}$ & 5 \\
\hline 18 & Transport & & & $\mathrm{x}$ & 12 \\
\hline 19 & Expert knowledge & $(\mathrm{x})$ & & $\mathrm{x}$ & 2 \\
\hline 20 & Normalization & $(\mathrm{x})$ & & $x$ & 3 \\
\hline
\end{tabular}

$\mathrm{x}$ : fully addressed site-dependent aspect; (x): partly addressed site-dependent aspect.

1. Acceptance: The analysis of the studies in the review revealed that site-dependent aspects can have an influence on the valuesphere of people and, therefore, have to be taken into account when assessing the sustainability of wood products. The actual beliefs and values of people are reflected in the acceptance and interests of various stakeholders in the region. Zuo et al. (2009) [156] describes this issue for the regional procurement of building materials for the purpose of reconstruction in Banda Aceh (Indonesia) after the tsunami hit the coast in 2004. Werner and Richter (2007) [157] see the different mental models and values of people as a result of the historical circumstances in the respective country and recommend the involvement of concerned stakeholders when preparing an LCA. Slocombe and van Bers (1992) [154] perceive an increased acceptance of ecological design-criteria if one is focused on a smaller area and denote this influencing factor as bio-regionalism.

2. National legislation: The institutional dimension of sustainability [158], i.e., the power of steering by national legislation or national action plans, plays a decisive role not only in the sustainable development of the European forest-based sector [159], but also in a public procurement that is increasingly guided by ecological criteria [148]. As opposed to green ideas manifested in laws and funding programs, voluntary certification schemes could not have successfully disseminated without the support and acceptance of the industry.

3. Country-specific certification schemes: For historical reasons, there are several country-specific certification schemes because they often started as national initiatives [42,107]. All certification schemes have certain requirements in common, but will keep their regional particularities until there is an overall global scheme implemented which substitutes them.

4. Regional forest inventory data: The whole carbon stock of a forest is dependent on the prevailing forest management regime [124]. To verify the stability of a forest's carbon stock, regional forest inventory data are required. For instance, boreal forests usually grow slower and, therefore, assimilate less carbon than forests in more temperate areas [160]. In contrast, the soil in the boreal zone is the most important carbon stock due to a slow decomposition at lower temperatures [161] and, nowadays, more and more threatened by global warming. Wolfslehner et al. (2013) [162] calculated the hardwood volume very precisely by means of a fixed radius sample plot and 
an angle count sampling. More often, researchers are forced to use less accurate estimations due to missing inventory data or knowledge about the true origin of the wooden material $[163,164]$. Only a completely documented chain-of-custody would allow a global traceability of wood.

5. Wood characteristics: Gustavsson and Sathre (2010) [165] as well as Nebel et al. (2006) [166] indicate in their studies that the forest biomass has to be distinguished in wood types and wood species if the forest production is part of an LCA. Not only do the different types of forest biomass differ in their range of material applications in the construction, furniture, or packaging sector due to their specific inherent properties, they also exhibit different biomass production rates and thus different carbon balances. Vogtländer et al. (2013) [116] mention in their study on carbon sequestration in wood products that data on specific wood types are not readily available for LCA practitioners, making even tier 2 calculations [167] of country-specific greenhouse gas inventories less accurate.

6. Land use: Another factor with a strong spatial dependence is land use. Changes in land use can have significant effects on the carbon balance within a wood cascade $[153,168]$. Furthermore, authors report on correlations with the climate at the habitat level of tropical forests [71], water balances due to changed evapotranspiration and outflows [52], and biodiversity through loss of habitats [120]. In the latter case, the authors see a rising awareness, but also difficulties in evaluating such correlations. García-Quijano et al. (2007) [72] recommend the establishment of a standardized global approach to assess the impact of land use effects, especially under the consideration of local management options. Allacker et al. (2014) [121] prefer the combination of two land use methods, soil organic matter [169] and Eco-indicator 99, for building LCAs. Fehrenbach et al. (2015) [140] use the hemeroby concept to consider land use in LCA by defining seven ordinal classes to appropriately characterize the naturalness of forest ecosystems. Slocombe and van Bers (1992) [154] suggest that timber production should be implemented on suitable forestry land only. However, one has to bear in mind that the use of wood-based materials in comparison to non-wood materials may show a poorer material efficiency resulting in a need of more land area or an intensified forest management $[165,170]$.

7. Biodiversity: In LCA, the use of indicators properly describing the loss of biodiversity is still under development. Land use as a proxy indicator for biodiversity is a popular approach $[125,171]$, but mainly focusing on species richness only. However, the number of species in an ecosystem is not the only determinant to measure changes in biodiversity $[120,172,173]$. Functional diversity can be the more reliable metric, as it connects species loss with ecosystem functions [174].

8. Water: Launiainen et al. (2013) [175] point out that local conditions also have to be considered when applying a water footprint methodology. They emphasize that the correct mapping of the spatial variability along the entire production chain of wood products is a crucial point for the calculation of their water use impacts.

9. Climate: The energy demand for heating and cooling of buildings may be, depending on the thermal mass of the building, more or less influenced by fluctuating climatic conditions [165]. Stazi et al. (2014) [81] reveal in their study that this region-specific parameter has a significant effect on the environmental burden of the chosen building envelope. Ultimately, they recommend a wooden lightweight envelope even if passive cooling techniques should be additionally applied in hot and dry climates.

10. Sample selection: Site-dependent aspects within the technosphere are primarily seen as attempts by researchers to methodically manage spatial variability. In comparative LCA, variability of products is usually addressed by contrasting a base case (default case, state-of-the-art) with one or more alternative cases (scenarios). In the case of wood products, spatial variability can be considered by the type of sample selection, e.g., by choosing different wood species from different vegetation zones. This was done by Feifel et al. (2015) [135] as well as Pommier et al. (2015) [90], who compared regional European pine wood with tropical wood from Africa. A prerequisite is that adequate local data exist to discover the differences in the biomass production and 
pre-processing of the timber. To get a representative picture of the environmental pressures caused by the timber industry in Ghana, Eshun et al. (2010) [125] paid attention to an appropriate regional distribution within their selected company sample. Furthermore, they calculated the local emissions based on the respective production volume. In the case of very large investigation areas, a subdivision can be useful to respect spatial variability. The fact that this subdivision does not have to be exclusively based on ecological criteria is shown in the study by Glazyrina et al. (2015) [176] who also used economic criteria such as tax revenues to cluster Russia into six not necessarily adjacent zones.

11. Combined methods: Another possibility to increase the site-dependent specificity of environmental product analyses is the combination of different scientific methodologies in the sense of a more interdisciplinary approach. Some authors make use of GIS in their investigations, for instance, to consider different speed limits in the analysis of transports [118] or to identify areas with a high inherent vulnerability [50]. Heuvelmans et al. (2005) [52] argue that showing the spatial variability of indicator scores with GIS layers delivers too much detail on a scenario where rather the total effect is of interest for decision-making. Apart from that, georeferenced analyses can be helpful for the identification of concrete areas where management actions primarily have to be implemented. Stazi et al. (2014) [81] used dynamic simulations to predict the energy consumption of a building and thereby increased the accuracy of the LCA results for the use phase. According to Tsang et al. (2014) [177], site-specific exposure pathways can be described more accurately by combining LCA with risk assessments. Wolfslehner and Vacik (2008) [44] brought up the idea of combining the Analytic Network Process (ANP) with the PSR framework in order to evaluate forest management strategies since PSR causally links human activities with changes in the state of ecosystems. Werner and Richter (2007) [157] recommend the combination of LCA with other sophisticated methods that are able to describe the manifold ecosystem services and functions of forests, thus indicating the true environmental value of wood products.

12. Country-specific tools: In some cases, it might be recommendable to use country-specific tools, i.e., exclusively tailored to national conditions, such as the TRACI model (Tool for Reduction and Assessment of Chemicals and Other Environmental Impacts) from US EPA (United States Environmental Protection Agency) to consider site-specific aspects in environmental modeling $[8,134,177,178]$.

13. Global value chains: Global value chains are characterized by an international dispersion of the different stages of a production process [179]. The Tool for Sustainability Impact Assessments of forest-wood-chains (ToSIA) supports the consideration of different locations along the value chain of a wood product by using indicator values that relate to the spatial boundary of the respective production stage $[34,43]$.

14. Country-specific databases: Single datasets in LCA databases such as ecoinvent are often developed in a European context. In order to allow a worldwide application without losing significance, they are often adapted to different geographical reference systems or used as a template for more generic, global datasets. For the same reason, life cycle impact assessment methods, such as Eco-indicator 95/99, need to be adapted to the respective geographical background [149]. In our sample, we found several studies making use of national databases or adapted datasets $[84,94,142,149,180-182]$ in order to get a more realistic picture of the prevailing electricity mix, technologies, or end-of-life scenarios in a respective country. Nevertheless, freely available or purchasable datasets often do not reflect the most recent state of technological developments.

15. Regional damage characterization factors: The magnitude of damages are highly dependent on the sensitivity of the respective ecosystem [183]. Therefore, several researchers criticize the fact that there are not enough regional characterization factors for damage assessments available in LCA, and that those that exists are often only valid for a European or North American 
background $[89,121,171,173]$. Nevertheless, the use of site-generic characterization factors can be acceptable if applied as a worst case scenario [171].

16. Scale: As indicators for SFM often emerge from a long-term political process of negotiation such as MCPFE with the intention of meeting worldwide interests, they may lose their relevance or validity on local scales [145], where "... SFM is embedded in a network of external and internal relationships" [97] (p. 167). To implement MCPFE in the national context of Austria, Wolfslehner and Vacik (2008) [44] therefore derived a smaller set of indicators that fit better to small-scale forestry. Another remedy to this problem can be the collection of input data at the process level [34]. The depletion of resources such as water and soil is often done on a global scale. However, the global perspective ignores the idea that site-dependent and more or less immobile resources cannot compensate each other or only at a great expense [184]. Therefore, Heuvelmans et al. (2005) [52] recommend a resource depletion assessment for water resources on a regional or local scale as well as a dynamic reserve life. Even if wood products are intended for indoor use only, they could have undergone chemical treatments that may later result in harmful emissions of volatile organic compounds. In favor of a better estimation of the human toxicity potential of treated wood products, a downscaling of environmental assessments to the indoor level is recommended by Jönsson (1999) [185] and Tarantini et al. (2011) [148]. According to Sharma et al. (2013) [50], assessments on a local scale are required for selecting appropriate resilience enhancement measures for a particular forest. On the contrary, Ianni and Geneletti (2010) [155] recommend forest restoration measures on the landscape level to include larger ecosystems as a whole.

17. Spatiotemporal dynamics: Similar to many scientific methodologies that are popular in practice, LCA is affected by the dilemma that an increase in accuracy requires a rise in complexity at the expense of practicability. However, some authors criticize the static character of the LCA concept that ignores the spatially and temporally dynamic interactions at the shared boundary of ecosphere and technosphere [123,157,185-187]. Heuvelmans et al. (2005) [52] introduced a new impact category (regional water balance) in their study to overstep classical system boundaries and enable better risk assessments for droughts and floods based on seasonal water quantities in agri- and silvicultural production systems.

18. Transport: In a globalized world, an important element of a wood product's life cycle is the transport whose environmental impact depends on the transport distances, transport weights, and transport means $[113,122,188]$. As the modeling of a transport process can be very complex and usually requires the application of a separate tool [118], authors in the sample of the review either used mean values as a rough approximation of the true transport distance [125] or run different transport scenarios (local to global) to evaluate the sensitivity of the overall outcome [119].

19. Expert knowledge: Lipušček et al. (2010) [183] recommend the involvement of local expert knowledge under the assumption that they can provide more reliable information on the sensitivity of a local or regional ecosystem than other external sources such as aggregated databases or national statistics. Expert opinion can also be valuable for the derivation of scenarios [95] and the weighting of life cycle inventory results [183].

20. Normalization: In case of life cycle assessments, the normalization of category indicator results constitutes an optional step to better assess their relevance in relation to a selected reference value [69]. In the sample, some authors used normalization with the intention to obtain a more representative product unit (e.g., size of deck surface per year of use) to allow product comparisons, where one product is set to 1.0, or to allow comparisons with the national average impacts for US families or the population of Europe [121,134]. 


\subsection{Support of Corporate Decision-Making}

With regard to the Triple Helix of state, science, and industry [70], the life cycle and site-dependent perspective of analysis as described above provide valuable insights for governmental agencies and researchers, whereas implications for the industry require deeper examination of the observed results. In exploring the results from the industry perspective we take the role of a decision-maker in an FMU and refer to contemporary performance measurement frameworks [48,49]. They distinguish between different levels for strategic and operational performance measurement: The collection of both financial and non-financial indicators constitutes the basic level of the system; their intended use is to inform decision-making and to evaluate organizational performance, in our context specifically the product life cycle of wood. The analysis of cause-and-effect relationships uses these indicators to derive a strategy. An advanced use of these indicators comprises the implementation of the strategy by defining objectives, action plans and results and connecting incentives with the indicators. Beyond the use for information and evaluation on an organizational level, the managerial performance is evaluated based on these indicators. A further differentiation includes monetary rewards. Only if our study's findings in terms of the identified environmental indicators are connected with the complex organizational processes will the results provide an added value to decision-making processes in industry.

Concerning the indicators as structured for the life cycle perspective, the state level and the pressure level are focused more on informational purposes, whereas the response level indicators can be directly used for corporate decision-making, e.g., the request for certified wood by customers leads to changes towards eco-design $[76,89,106]$. From none of the publications could we derive the use for cause-effect analysis along the whole life cycle of a wood product or even for performance evaluation.

Concerning the region-specific analysis, the social perspective is highly relevant for decision-making: Only if eco-design criteria are accepted and supported by national legislation and/or certification schemes do decision-makers feel encouraged to promote them. Ecosystem indicators are only partially relevant for industry-specific use: wood characteristics might be relevant for customization of products, water availability might drive the selection of production processes, and climate change might gain importance for a wide range of stakeholders. Methodological aspects might appear relevant for science only. However, a closer look reveals their indirect importance for several criteria: Country specific adaptation might be appropriate whenever the criteria or their values differ between countries, such as for acceptance or legislation, but also for ecosystem characteristics such as water availability. Global value chains involve an explicit decision regarding which parts shall be included in the corporate strategy.

Of course, not all of the mentioned indicators may be applicable for every practitioner as they are often subject to unbundled responsibilities in an organization and embedded in various corporate guidance such as material safety data sheets (MSDS) or fire safety regulations.

\section{Conclusions}

The review of 118 publications provides a comprehensive overview of indicators and methods that have been used by researchers and practitioners to evaluate the environmental dimension of sustainability of wood products. Key principles and indicators for the sustainable use of wood resources and wood products have been identified in the literature originating from different stakeholder groups and covering different stages of the wood product's life cycle. It emerged from the analysis that LCA is the prevailing method to determine the environmental impacts of wood products. In order to overcome the shortcomings of LCA in terms of linear process modeling, temporal and spatial uncertainties, and inconsistently chosen system boundaries [189], many researchers combine LCA with other common methods such as eco-design principles, MCDA, and numeric, ecosystem-based modeling to address the complex characteristics of wood products. Site-dependent aspects could be identified for the forest ecosystem itself, the applied scientific methodology, and the respective valuesphere of researchers or other stakeholders, which demonstrates their relevance 
for the environmental assessment of wood products. The involvement of local expert knowledge, the collection of additional environmental information of affected ecosystems as well as the application of flexible and extendable models can help to better address such site-dependent aspects. Finally, the indicators can be used for decision-making towards eco-design, but also for resource considerate purchasing and processing.

Further research demands mentioned in more recent studies mainly refer to the improvement of LCA, e.g., through the accounting of biotic resources [121], the consideration of the technical performance of building materials [180], the quantification of ecosystem services [139,157,164], the attributional allocation of long-lived products [190], the assessment of forest carbon dynamics including carbon tracking and soil carbon $[143,145,165]$, the provision of interfaces to other modeling tools [191], the development of regional characterization factors for land use change [121], water balance [52,72] and biodiversity [72,171], and, finally, the increased application of such new approaches in case studies $[123,138,154]$. Moreover, the investigation of the influence of design decisions on the product quality and environmental performance of products is encouraged [82,192]. Besides a better availability of industrial data and user-friendly assessment tools [77,140,193], a more interdisciplinary sustainability research in principle is recommended [41,194]. Furthermore, stakeholders should be more often integrated in the analysis, e.g., for the development of weighting factors, to ensure a higher acceptance of the LCA results $[19,34,41,187]$. As the use of long-lived products, especially in furnishing, conflict with the short period of trends, we see additional socio-economic research demands concerning the acceptance and preferences of consumers. Saravia-Cortez et al. (2013) [195] also point to a possible impairment of the wood products' quality through the higher usage of recycled ingredients.

In recent studies from Bach et al. (2017) [196] and Crenna et al. (2017) [18], both devoted to the conceptual development of LCA, indicator-based frameworks are presented that allow the integration of diverse biotic resources into LCA. In respecting cause-and-effect relationships, different origins of biotic resources (natural and man-made resources), and constraints for the availability of biotic resources, such conceptual developments can be promising for the future evaluation of wood products.

Having collected a variety of indicators within this review, we recommend a combination of indicators from all three aspects of the PSR framework for a holistic environmental assessment of wood products. We cannot finally say what the best combination of indicators and methods is because this would first require an investigation on the maturity of indicators with respect to criteria such as practicability and ecological effectiveness. Nevertheless, we consider our overview as a first step towards closing this research gap. Concerning the proliferation of resource-efficient and environmentally beneficial wood products, a subsequent step could be a comparative, extended life cycle assessment of wood products within a common scope but differing in their origin of the forest resource, tree species, production technology, end-of-life, and technical aspects such as weather resistance.

Supplementary Materials: The following are available online at www.mdpi.com/2071-1050/9/10/1897/s1. Table S1: Search protocol; Table S2: Overview of 118 studies included in the review; Table S3: Overview of MAXQDA categories, main codes and subcodes; Table S4: PRISMA Checklist.

Acknowledgments: This work is financially supported by the Federal Ministry of Education and Research (BMBF) in the scope of the leading-edge Cluster BioEconomy (grant number 031A068A/PtJ, project 1.4 Faserverstärkte Formholzprodukte aus Buche; grant number 031A441A/PtJ, project Masten aus Form- und Furnierholz in Buche, VP1.12 BEECHPOLE). We further acknowledge support by the German Research Foundation and the Open Access Publication Funds of the TU Dresden.

Author Contributions: Nadine May conducted the systematic literature review and wrote the paper. Edeltraud Guenther supported the conception of the review, revised the review results, supported the interpretation of the results, and wrote the discussion on corporate decision-making. Peer Haller supported the conception of the review and revised the review results and drawn conclusions.

Conflicts of Interest: The authors declare no conflict of interest. The funding sponsors had no role in the design of the study, in the collection, analyses, or interpretation of data, in the writing of the manuscript, and in the decision to publish the results. 


\section{Appendix A}

Table A1. Origin of indicators $\left(\mathrm{N}_{\mathrm{cod}}=147, \mathrm{~N}_{\mathrm{doc}}=118\right)$.

\begin{tabular}{|c|c|c|}
\hline Stakeholder Group & Initiative & Codings \\
\hline \multirow[t]{16}{*}{ Policy } & Classification-Based Forest Management (CFM) China & 1 \\
\hline & German National Forest Program/Nationales Waldprogramm (NWP) & 1 \\
\hline & Sustainable Impact Assessment Guidelines (SIA) $\left(\mathrm{EC}^{1}\right)$ & 1 \\
\hline & Kreislaufwirtschaftsgesetz/Altholzverordnung & 1 \\
\hline & Municipal Solid Waste Decision Support Tool (US EPA) & 1 \\
\hline & Forest Law Enforcement, Governance and Trade (FLEGT) (EU) & 1 \\
\hline & Nordic Ecolabel & 1 \\
\hline & EU Ecolabel & 1 \\
\hline & Kyoto Protocol (UN) & 1 \\
\hline & Montreal Process & 1 \\
\hline & The Ecosystem Approach (UNCED) & 1 \\
\hline & Pressure-State-Response framework (OECD) & 2 \\
\hline & Sustainable Development Indicators (SDI) (Eurostat) & 2 \\
\hline & SDI (UN Commission on Sustainable Development) & 2 \\
\hline & Pan-European Indicators (MCPFE) & 6 \\
\hline & TRACI (US EPA) & 8 \\
\hline \multirow[t]{5}{*}{ Policy-Science } & EcoMark Japan (Japan Environment Association, NPO ²) & 1 \\
\hline & European Union Rural Indicators (PAIS ${ }^{3}$-Project, Eurostat) & 2 \\
\hline & Forest Landscape Restoration (FLR) $\left(\mathrm{IUCN}^{4}-\mathrm{WWF}^{5}\right)$ & 1 \\
\hline & USEtox $^{\circledR}\left(\right.$ UNEP $^{6}{ }^{-}$SETAC $\left.^{7}\right)$ & 2 \\
\hline & Intergovernmental Panel on Climate Change (IPCC, UN) & 3 \\
\hline \multirow[t]{9}{*}{ Science } & Biodiversity damage potential-land use & 1 \\
\hline & Life Support Function (LSF)-land use & 1 \\
\hline & Soil Organic Carbon (SOC)-land use & 1 \\
\hline & Hemeroby-land use & 1 \\
\hline & Ecological footprint & 1 \\
\hline & Lipasto emission calculation $\left(\mathrm{VTT}^{8}\right)$ & 1 \\
\hline & Water Footprint Network (NPO) & 1 \\
\hline & Simulation & 1 \\
\hline & Literature & 7 \\
\hline \multirow[t]{3}{*}{ Science-Industry } & Environmental Priority Strategies (EPS 2000) & 1 \\
\hline & LANCA $^{\circledR 9}$ land use & 1 \\
\hline & natureplus label (construction) & 1 \\
\hline \multirow[t]{10}{*}{ Industry } & BIFMA ${ }^{10}$ Level Scorecared (furniture) (NPO) US & 1 \\
\hline & Cradle2Cradle (NPO) (US) & 1 \\
\hline & EcoLogo environmental choice (Underwriters Laboratories) Canada & 1 \\
\hline & Floorscore (Scientific Certification Systems) US & 1 \\
\hline & Greenguard (Underwriters Laboratories) US & 1 \\
\hline & Indoor advantage gold (Scientific Certification Systems) US & 1 \\
\hline & Indoor advantage (Scientific Certification Systems) US & 1 \\
\hline & DIN EN 15978 (2012) & 1 \\
\hline & INIES $^{11}\left(\right.$ EPD $^{12} /$ FDES $\left.^{13}\right)$ & 1 \\
\hline & SmaRT $^{14}\left(\mathrm{MTS}^{15}\right)$ (NPO) US & 1 \\
\hline \multirow[t]{10}{*}{ Policy-Science-Industry } & Blue Angel & 1 \\
\hline & Canadian Standards Association (CSA) (NPO) & 3 \\
\hline & Sustainable Green Ecosystem Council Japan (SGEC) (NPO) & 1 \\
\hline & Eco-Indicator 95/99 & 13 \\
\hline & ReCiPe & 8 \\
\hline & LEED $^{16}$ points $\left(\right.$ USGBC $\left.^{17}\right)(\mathrm{NPO})$ & 1 \\
\hline & NF Environment furniture $\left(A F N O R{ }^{18}\right)$ France & 1 \\
\hline & $\mathrm{SFI}^{19}(\mathrm{NPO})$ & 3 \\
\hline & PEFC (NPO) & 6 \\
\hline & FSC (NPO) & 8 \\
\hline
\end{tabular}

${ }^{1}$ EC: European Commission; ${ }^{2}$ NPO: Non-profit organization; ${ }^{3}$ PAIS: Proposal on Agri-Environmental Indicators; ${ }^{4}$ IUCN: International Union for Conservation of Nature; ${ }^{5}$ WWF: World Wide Fund for Nature; ${ }^{6}$ UNEP: United Nations Environment Programme; ${ }^{7}$ SETAC: Society of Environmental Toxicology and Chemistry; ${ }^{8}$ VTT: Technical Research Centre of Finland; ${ }^{9}$ LANCA®: Land Use Indicator Value Calculation Tool; ${ }^{10}$ BIFMA: Business and Institutional Furniture Manufacturer's Association; ${ }^{11}$ INIES: Les données environnementales et sanitaires de référence pour le bâtiment; ${ }^{12}$ EPD: Enviornmental Product Declaration; ${ }^{13}$ FDES: Environmental and Health Product Declaration (French); ${ }^{14}$ SMaRT: National Consensus Sustainable Product Standard; ${ }^{15}$ MTS: Institute for Market Transformation to Sustainability; ${ }^{16}$ LEED: Leadership in Energy and Environmental Design; ${ }^{17}$ USGBC: US Green Building Council; ${ }^{18}$ AFNOR: Association française de normalization; ${ }^{19}$ SFI: Sustainable Forestry Initiative. 


\section{References}

1. United Nations. Sustainable Development Goals, Transforming Our World: The 2030 Agenda for Sustainable Development. Available online: http:/ / www.un.org/sustainabledevelopment/sustainable-developmentgoals / (accessed on 31 August 2017).

2. Hart, S.L. A Natural-Resource-Based View of the Firm. Acad. Manag. Rev. 1995, 20, 986-1014. [CrossRef]

3. Henckens, M.L.C.M.; Driessen, P.P.J.; Worrell, E. How can we adapt to geological scarcity of antimony? Investigation of antimony's substitutability and of other measures to achieve a sustainable use. Resour. Conserv. Recycl. 2016, 108, 54-62. [CrossRef]

4. Schoolderman, H.; Mathlener, R. Minerals and Metals Scarcity in Manufacturing: The Ticking Time Bomb, Sustainable Materials Management; Price Waterhouse Coopers Accountants: London, UK, 2011.

5. Sampson, R.N.; Bystriakova, N.; Brown, S.; Gonzalez, P.; Irland, L.C.; Kauppi, P.; Sedjo, R.; Thompson, I.D.; Barber, C.V.; Offrell, R. Chapter 9: Timber, Fuel and Fiber. In Ecosystems and Human Well-Being: Current State and Trends, Volume 1: Findings of the CONDITION and Trends Working Group; Hassan, R.M., Scholes, R., Ash, N., Eds.; Island Press: Washington, DC, USA, 2005; Volume 1, pp. 243-269.

6. Schweinle, J. Wood \& other renewable resources: A challenge for LCA. Int. J. Life Cycle Assess. 2007, $12,141$. [CrossRef]

7. Haller, P.; Putzger, R.; Wehsener, J.; Hartig, J. Formholzrohre-Stand der Forschung und Anwendungen. Bautechnik 2013, 90, 34-41. [CrossRef]

8. Bolin, C.A.; Smith, S.T. Life cycle assessment of pentachlorophenol-treated wooden utility poles with comparisons to steel and concrete utility poles. Renew. Sustain. Energy Rev. 2011, 15, 2475-2486. [CrossRef]

9. Brack, D. Controlling Illegal Logging and the Trade in Illegally Harvested Timber: The EU's Forest Law Enforcement, Governance and Trade Initiative. Rev. Eur. Commun. Int. Environ. Law 2005, 14. [CrossRef]

10. Dykstra, D.P.; Kuru, G.; Taylor, R.; Nussbaum, R.; Magrath, W.; Story, J. Technologies for Wood Tracking: Verifying and Monitoring the Chain of Custody and Legal Compliance in the Timber Industry; World Bank/WWF Alliance for Forest Conservation and Sustainable Use: Washington, DC, USA, 2002; p. 88.

11. Coulson, J. Sustainable Use of Wood in Construction: Chapter 3: Voluntary Timber Certification Schemes; Wiley: Hoboken, NJ, USA, 2014; pp. 41-64. ISBN 9781118539613.

12. Seppelt, R.; Manceur, A.M.; Liu, J.; Fenichel, E.P.; Klotz, S. Synchronized peak-rate years of global resources use. Ecol. Soc. 2014, 19, 50. [CrossRef]

13. TEEB. The Economics of Ecosystems and Biodiversity Ecological and Economic Foundations: Chapter 1 Integrating the Ecological and Economic Dimensions in Biodiversity and Ecosystem Service Valuation; Pushpam Kumar, Earthscan: London, UK; Washington, DC, USA, 2010; pp. 1-422.

14. Federal Ministry of Food, Agriculture and Consumer Protection (BMELV). Forest Strategy 2020: Sustainable Forest Management-An Opportunity and a Challenge for Society; BMELV: Bonn, Germany, 2011; pp. 1-36. Available online: http:/ / www.bmel.de/SharedDocs/Downloads/EN/Publications/ForestStrategy2020.pdf (accessed on 31 August 2017).

15. Sächsisches Staatsministerium für Umwelt und Landwirtschaft (SMUL). Waldstrategie 2050 Für Den Freistaat Sachsen; SMUL: Dresden, Germany, 2013; pp. 1-48. Available online: https:/ / publikationen.sachsen.de/ bdb/artikel/11309 (accessed on 31 August 2017).

16. European Commission (EC). Innovating for Sustainable Growth: A Bioeconomy for Europe: Communication from the Commission to the European Parliament, the Council, the European economic and social Committee and the Committee of the Regions; EC: Brussels, Belgium, 2012; pp. 1-9. Available online: http:/ / ec.europa.eu/ research/bioeconomy/pdf/201202_innovating_sustainable_growth_en.pdf (accessed on 31 August 2017).

17. Ashby, M.F. Materials Selection in Mechanical Design, 4th ed.; Elsevier/Butterworth-Heinemann: Amsterdam, The Netherland, 2010; pp. 1-646. ISBN 1856176630.

18. Crenna, E.; Sozzo, S.; Sala, S. Natural biotic resources in LCA: Towards an impact assessment model for sustainable supply chain management. J. Clean. Prod. 2017. [CrossRef]

19. Prabhu, R.; Colfer, C.J.P.; Dudley, R.G. Guidelines for Developing, Testing and Selecting Criteria and Indicators for Sustainable Forest Management: A CEI Developer's Reference; Center for International Forestry Research (CIFOR): Jakarta, Indonesia, 1999; pp. 1-183. ISBN 9798764242.

20. Food and Agriculture Organization of the United Nations. State of the World's Forests 1997; FAO: Rome, Italy, 1997; pp. 1-200, ISBN 9789251039779. 
21. United Nations (UN). Agenda 21: Chapter 11 combating deforestation. In Proceedings of the United Nations Conference on Environment and Development (UNCED), Rio de Janerio, Brazil, 3-14 June 1992; UN: New York, NY, USA, 1992; p. 351. Available online: https://sustainabledevelopment.un.org/ outcomedocuments/agenda21 (accessed on 3 October 2017).

22. United Nations. Forest Principles: A/CONF.151/26 (Vol. III), Non-legally binding authoritative statement of principles for a global consensus on the management, conservation and sustainable development of all types of forests. In Proceedings of the United Nations Conference on Environment and Development (UNCED), Rio de Janeiro, Brazil, 3-14 June 1992. Available online: http:/ / www.un.org/documents/ga/ conf151/aconf15126-3annex3.htm (accessed on 3 October 2017).

23. Organisation for Economic Co-Operation and Development (OECD). Core Set of Indicators for Environmental Performance Reviews: A Synthesis Report by the Group on the State of the Environment; OECD: Paris, France, 1993; pp. 1-39. Available online: http:/ / enrin.grida.no/htmls/armenia/soe2000/eng/oecdind.pdf (accessed on 31 August 2017).

24. Walz, R. Development of Environmental Indicator Systems: Experiences from Germany. Environ. Manag. 2000, 25, 613-623. [CrossRef] [PubMed]

25. Hammond, A.; Adriaanse, A.; Rodenburg, E.; Bryant, D.; Woodward, R. Environmental Indicators: A Systematic Approach to Measuring and Reporting on Environmental Policy Performance in the Context of Sustainable Development; World Resources Institute: Washington, DC, USA, 1995; pp. 1-58, ISBN 1569730261.

26. Giegrich, J. Bilanzbewertung in produktbezogenen Ökobilanzen: Evaluation von Bewertungsmethoden, Perspektiven. In Methodik der Produktbezogenen Ökobilanzen; Umweltbundesamt: Berlin, Germany, 1995; pp. 255-279.

27. European Forest Institute (EFI). Implementing Criteria and Indicators for Sustainable Forest Management in Europe; EFI: Joensuu, Finland, 2013; pp. 1-132. Available online: http:/ /www.efi.int/files/attachments / publications/efi_c-i_report_implementing_criteria_net_final.pdf (accessed on 31 August 2017).

28. Ministerial Conference on the Protection of Forests in Europe (MCPFE). Improved Pan-European Indicators for Sustainable Forest Management: As Adopted by the MCPFE Expert Level Meeting 7-8 October 2002; MCPFE: Vienna, Austria, 2003; pp. 1-6. Available online: http:/ / www.foresteurope.org/documentos/improved_ indicators.pdf (accessed on 31 August 2017).

29. FSC. Forest Stewardship Council. 2017. Available online: https:/ / www.fsc.org (accessed on 28 June 2017).

30. PEFC. Programme for the Endorsement of Forest Certification. 2017. Available online: https://www.pefc.org (accessed on 28 June 2017).

31. Yadav, M. Handbook on Forest Certification; The Energy and Resources Institute (TERI): New Delhi, India, 2016; ISBN 9788179933008.

32. Wingate, K.G.; McFarlane, P.N. Chain of custody and eco-labelling of forest products: A review of the requirements of the major forest certification schemes. Int. For. Rev. 2005, 7, 342-347. [CrossRef]

33. Werner, F.; Althaus, H.-J.; Künninger, T.; Richter, K.; Jungbluth, N. Life Cycle Inventories of Wood as Fuel and Construction Material; Final Report Ecoinvent 2000 No. 9; EMPA: Dübendorf, Switzerland; ESU-Services: Uster, Switzerland, 2007; pp. 1-176.

34. Lindner, M.; Suominen, T.; Palosuo, T.; Garcia-Gonzalo, J.; Verweij, P.; Zudin, S.; Päivinen, R. ToSIA-A tool for sustainability impact assessment of forest-wood-chains. Ecol. Model. 2010, 221, 2197-2205. [CrossRef]

35. Ecoinvent Association. Ecoinvent Database. 2017. Available online: http:/ /www.ecoinvent.org/database/ database.html (accessed on 2 October 2017).

36. Thinkstep. GaBi LCA Databases. 2017. Available online: http://www.gabi-software.com/international/ databases/gabi-databases/ (accessed on 2 October 2017).

37. Umweltbundesamt. ProBas: Prozessorientierte Basisdaten für Umweltmanagementsysteme. 2017. Available online: http:/ / www.probas.umweltbundesamt.de/php/index.php (accessed on 2 October 2017).

38. Frischknecht, R.; Jungbluth, N.; Althaus, H.-J.; Doka, G.; Dones, R.; Heck, T.; Hellweg, S.; Hischier, R.; Nemecek, T.; Rebitzer, G.; et al. Ecoinvent Version 2: Final Report Ecoinvent Data v2.0, No. 1; Swiss Centre for Life Cycle Inventories: Dübendorf, Switzerland, 2007.

39. World Business Council for Sustainable Development (WBCSD); European Partners for the Environment (EPE). European Eco-Efficiency Initiatives; a Road Map for Business Strategy and Government Action; WBCSD/EPE: Brussels, Belgium; Geneva, Switzerland, 1999. 
40. Calkins, M. Materials for Sustainable Sites: A Complete Guide to the Evaluation, Selection, and Use of Sustainable Construction Materials; Wiley: Hoboken, NJ, USA, 2009; pp. 1-480, ISBN 9781281837028.

41. Von Geibler, J.; Kristof, K.; Bienge, K. Sustainability assessment of entire forest value chains: Integrating stakeholder perspectives and indicators in decision support tools. Ecol. Model. 2010, 221, 2206-2214. [CrossRef]

42. Cobut, A.; Beauregard, R.; Blanchet, P. Using life cycle thinking to analyze environmental labeling: The case of appearance wood products. Int. J. Life Cycle Assess. 2012, 18, 722-742. [CrossRef]

43. Palosuo, T.; Suominen, T.; Werhahn-Mees, W.; Garcia-Gonzalo, J.; Lindner, M. Assigning results of the Tool for Sustainability Impact Assessment (ToSIA) to products of a forest-wood-chain. Ecol. Model. 2010, 221, 2215-2225. [CrossRef]

44. Wolfslehner, B.; Vacik, H. Evaluating sustainable forest management strategies with the Analytic Network Process in a Pressure-State-Response framework. J. Environ. Manag. 2008, 88, 1-10. [CrossRef] [PubMed]

45. Niemeijer, D.; Groot, R.S.D. A conceptual framework for selecting environmental indicator sets. Ecol. Indic. 2008, 8, 14-25. [CrossRef]

46. European Environment Agency (EEA). Environment in the European Union at the Turn of the Century; Report No. 2; EEA: Copenhagen, Danmark, 1999; pp. 1-446. Available online: https:/ /www.eea.europa.eu/ publications/92-9157-202-0 (accessed on 31 August 2017).

47. Spangenberg, J.H.; Pfahl, S.; Deller, K. Towards indicators for institutional sustainability: Lessons from an analysis of Agenda 21. Ecol. Indic. 2002, 2, 61-77. [CrossRef]

48. Franco-Santos, M.; Lucianetti, L.; Bourne, M. Contemporary performance measurement systems: A review of their consequences and a framework for research. Manag. Account. Res. 2012, 23, 79-119. [CrossRef]

49. Speckbacher, G.; Bischof, J.; Pfeiffer, T. A descriptive analysis on the implementation of Balanced Scorecards in German-speaking countries. Manag. Account. Res. 2003, 14, 361-388. [CrossRef]

50. Sharma, J.; Chaturvedi, R.K.; Bala, G.; Ravindranath, N.H. Assessing "inherent vulnerability" of forests: a methodological approach and a case study from Western Ghats, India. Mitig. Adapt. Strateg. Glob. Chang. 2013, 20, 573-590. [CrossRef]

51. Sharma, J.; Chaturvedi, R.K.; Bala, G. Challenges in vulnerability assessment of forests under climate change. Carbon. Manag. 2013, 4, 403-411. [CrossRef]

52. Heuvelmans, G.; Muys, B.; Feyen, J. Extending the life cycle methodology to cover impacts of land use systems on the water balance. Int. J. Life Cycle Assess. 2005, 10, 113-119. [CrossRef]

53. Hofstetter, P. Perspectives in Life Cycle Impact Assessment: A Structured Approach to Combine Models of the Technosphere, Ecosphere and Valuesphere; Springer: Boston, MA, USA, 1998; pp. 1-484, ISBN 9780792383772.

54. Zhewen, F.; Musheng, L.; Wenqing, S.; Liansheng, L. GIS-Based Assessment on Eco-vulnerability of Jiangxi Province. In Proceedings of the International Conference on Environmental Science and Information Application Technology (ESIAT), Wuhan, China, 4-5 July 2009; pp. 426-431.

55. Ahmadi Sani, N.; Babaie Kafaky, S.; Pukkala, T.; Mataji, A. Integrated use of GIS, remote sensing and multi-criteria decision analysis to assess ecological land suitability in multi-functional forestry. J. For. Res. 2016, 27, 1127-1135. [CrossRef]

56. Latinopoulos, D.; Kechagia, K. A GIS-based multi-criteria evaluation for wind farm site selection. A regional scale application in Greece. Renew. Energ. 2015, 78, 550-560. [CrossRef]

57. Neshat, A.; Pradhan, B.; Shafri, H.Z.M. An Integrated GIS Based Statistical Model to Compute Groundwater Vulnerability Index for Decision Maker in Agricultural Area. J. Indian Soc. Remote 2014, 42, 777-788. [CrossRef]

58. Alvarenga, R.A.F.; Dewulf, J.; Van Langenhove, H.; Huijbregts, M.A.J. Exergy-based accounting for land as a natural resource in life cycle assessment. Int. J. Life Cycle Assess. 2013, 18, 939-947. [CrossRef]

59. Tranfield, D.; Denyer, D.; Smart, P. Towards a Methodology for Developing Evidence-Informed Management Knowledge by Means of Systematic Review. Br. J. Manag. 2003, 14, 207-222. [CrossRef]

60. Fink, A. Conducting Research Literature Reviews: From the Internet to Paper; SAGE Publ: Los Angeles, CA, USA, 2014; pp. 1-257, ISBN 9781452259499.

61. Littell, J.H.; Corcoran, J.; Pillai, V. Systematic Reviews and Meta-Analysis; Oxford University Press: New York, NY, USA, 2008; pp. 1-216, ISBN 9780195326543.

62. Zumsteg, J.M.; Cooper, J.S.; Noon, M.S. Systematic Review Checklist. J. Ind. Ecol. 2012, 16, S12-S21. [CrossRef] [PubMed] 
63. Moher, D.; Liberati, A.; Tetzlaff, J.; Altman, D.G.; Group, T.P. Preferred Reporting Items for Systematic Reviews and Meta-Analyses: The PRISMA Statement. PLoS Med. 2009, 6, e1000097. [CrossRef] [PubMed]

64. Cooper, H.M. Scientific Guidelines for Conducting Integrative Research Reviews. Rev. Educ. Res. 1982, 52, 291-302. [CrossRef]

65. Verbi GmbH. MAXQDA Standard 12: Release 12.3.0; Verbi GmbH: Berlin, Germany, 2017.

66. Krippendorff, K. Content Analysis: An Introduction to Its Methodology; SAGE Publisher: Los Angeles, CA, USA, 2013; pp. 1-441, ISBN 9781412983150.

67. Mayring, P. Qualitative Inhaltsanalyse: Grundlagen und Techniken, 11th ed; Beltz: Weinheim, Germany, 2010; pp. 1-144, ISBN 3407291426.

68. Holsti, O.R. Content Analysis for the Social Sciences and Humanities; Addison-Wesley: Reading, MA, USA, 1969; pp. 1-235, ISBN 0201029405.

69. Deutsches Institut für Normung. Environmental Management_Life Cycle Assessment-Requirements and Guidelines; EN ISO 14044:2006, ICS 13.020.10; Beuth Verlag GmbH: Berlin, Germany, 2006; pp. 1-84. Available online: https:/ / www.iso.org/standard/38498.html (accessed on 31 August 2017).

70. Etzkowitz, H.; Leydesdorff, L. The dynamics of innovation: From National Systems and "Mode 2" to a Triple Helix of university-industry-government relations. Res. Policy 2000, 29, 109-123. [CrossRef]

71. Davidson, J. Economic use of tropical moist forests while maintaining biological, physical and social values. Environmentalist 1985, 5, 3-28. [CrossRef]

72. García-Quijano, J.F.; Peters, J.; Cockx, L.; Van Wyk, G.; Rosanov, A.; Deckmyn, G.; Ceulemans, R.; Ward, S.M.; Holden, N.M.; Van Orshoven, J.; et al. Carbon sequestration and environmental effects of afforestation with Pinus radiata D. Don in the Western Cape, South Africa. Clim. Chang. 2007, 83, 323-355. [CrossRef]

73. Grant, A.; Ries, R.; Kibert, C. Life Cycle Assessment and Service Life Prediction A Case Study of Building Envelope Materials. J. Ind. Ecol. 2014, 18, 187-200. [CrossRef]

74. Höglmeier, K.; Steubing, B.; Weber-Blaschke, G.; Richter, K. LCA-based optimization of wood utilization under special consideration of a cascading use of wood. J. Environ. Manag. 2015, 152, 158-170. [CrossRef] [PubMed]

75. Hollberg, A.; Ruth, J. LCA in architectural design-A parametric approach. Int. J. Life Cycle Assess. 2016, 21, 943-960. [CrossRef]

76. Jrade, A.; Jalaei, F. Integrating building information modelling with sustainability to design building projects at the conceptual stage. Build. Simul. 2013, 6, 429-444. [CrossRef]

77. Klein, D.; Wolf, C.; Schulz, C.; Weber-Blaschke, G. Environmental impacts of various biomass supply chains for the provision of raw wood in Bavaria, Germany, with focus on climate change. Sci. Total Environ. 2016, 539, 45-60. [CrossRef] [PubMed]

78. Monteiro, H.; Freire, F. Life-cycle assessment of a house with alternative exterior walls: Comparison of three impact assessment methods. Energy Build. 2012, 47, 572-583. [CrossRef]

79. Motuzienè, V.; Rogoža, A.; Lapinskienè, V.; Vilutienė, T. Construction solutions for energy efficient single-family house based on its life cycle multi-criteria analysis: A case study. J. Clean. Prod. 2016, 112, 532-541. [CrossRef]

80. Pingoud, K.; Ekholm, T.; Savolainen, I. Global warming potential factors and warming payback time as climate indicators of forest biomass use. Mitig. Adapt. Strateg. Glob. Chang. 2011, 17, 369-386. [CrossRef]

81. Stazi, F.; Tomassoni, E.; Bonfigli, C.; Di Perna, C. Energy, comfort and environmental assessment of different building envelope techniques in a Mediterranean climate with a hot dry summer. Appl. Energy 2014, 134, 176-196. [CrossRef]

82. Zhang, W.; Tan, S.; Lei, Y.; Wang, S. Life cycle assessment of a single-family residential building in Canada: A case study. Build. Simul. 2013, 7, 429-438. [CrossRef]

83. Bovea, M.D.; Vidal, R. Materials selection for sustainable product design: A case study of wood based furniture eco-design. Mater. Des. 2004, 25, 111-116. [CrossRef]

84. Çinar, H. Eco-design and furniture: Environmental impacts of wood-based panels, surface and edge finishes. For. Prod. J. 2005, 55, 27-33.

85. González-García, S.; García Lozano, R.; Buyo, P.; Pascual, R.C.; Gabarrell, X.; Rieradevall i Pons, J.; Moreira, M.T.; Feijoo, G. Eco-innovation of a wooden based modular social playground: Application of LCA and DfE methodologies. J. Clean. Prod. 2012, 27, 21-31. [CrossRef] 
86. González-García, S.; García Lozano, R.; Moreira, M.T.; Gabarrell, X.; Rieradevall i Pons, J.; Feijoo, G.; Murphy, R.J. Eco-innovation of a wooden childhood furniture set: An example of environmental solutions in the wood sector. Sci. Total Environ. 2012, 426, 318-326. [CrossRef] [PubMed]

87. González-García, S.; Lozano, R.G.; Estévez, J.C.; Pascual, R.C.; Moreira, M.T.; Gabarrell, X.; Rieradevall i Pons, J.; Feijoo, G. Environmental assessment and improvement alternatives of a ventilated wooden wall from LCA and DfE perspective. Int. J. Life Cycle Assess. 2012, 17, 432-443. [CrossRef]

88. González-García, S.; Gasol, C.M.; Lozano, R.G.; Moreira, M.T.; Gabarrell, X.; Rieradevall i Pons, J.; Feijoo, G. Assessing the global warming potential of wooden products from the furniture sector to improve their ecodesign. Sci. Total Environ. 2011, 410-411, 16-25. [CrossRef] [PubMed]

89. Mirabella, N.; Castellani, V.; Sala, S. LCA for assessing environmental benefit of eco-design strategies and forest wood short supply chain: A furniture case study. Int. J. Life Cycle Assess. 2014, 19, 1536-1550. [CrossRef]

90. Pommier, R.; Grimaud, G.; Prinçaud, M.; Perry, N.; Sonnemann, G. Comparative environmental life cycle assessment of materials in wooden boat ecodesign. Int. J. Life Cycle Assess. 2015, 21, 265-275. [CrossRef]

91. Strömberg, L. Integrated life-cycle design of coatings on exterior wood: Part 2: Life-cycle assessment. Surf. Coat. Int. Part B Coat. Trans. 2004, 87, 211-220. [CrossRef]

92. Frenette, C.D.; Bulle, C.; Beauregard, R.; Salenikovich, A.; Derome, D. Using life cycle assessment to derive an environmental index for light-frame wood wall assemblies. Build. Environ. 2010, 45, 2111-2122. [CrossRef]

93. Oblak, L.; Jost, M. Methodology for Studying the Ecological Quality of Furniture. Drona Industrija 2011, 62, 171-176. [CrossRef]

94. Rieradevall i Pons, O.; Aguado, A. Integrated value model for sustainable assessment applied to technologies used to build schools in Catalonia, Spain. Build. Environ. 2012, 53, 49-58. [CrossRef]

95. Tsang, M.P.; Bates, M.E.; Madison, M.; Linkov, I. Benefits and Risks of Emerging Technologies: Integrating Life Cycle Assessment and Decision Analysis To Assess Lumber Treatment Alternatives. Environ. Sci. Technol. 2014, 48, 11543-11550. [CrossRef] [PubMed]

96. Päivinen, R.; Lindner, M.; Rosén, K.; Lexer, M.J. A concept for assessing sustainability impacts of forestry-wood chains. Eur. J. For. Res. 2010, 131, 7-19. [CrossRef]

97. Wolfslehner, B.; Vacik, H.; Lexer, M.J. Application of the analytic network process in multi-criteria analysis of sustainable forest management. For. Ecol. Manag. 2005, 207, 157-170. [CrossRef]

98. Berninger, K.; Adamowicz, W.; Kneeshaw, D.; Messier, C. Sustainable Forest Management Preferences of Interest Groups in Three Regions with Different Levels of Industrial Forestry: An Exploratory Attribute-Based Choice Experiment. Environ. Manag. 2010, 46, 117-133. [CrossRef] [PubMed]

99. Eve, E.; Arguelles, F.A.; Fearnside, P.M. How Well Does Brazil's Environmental Law Work in Practice? Environmental Impact Assessment and the Case of the Itapiranga Private Sustainable Logging Plan. Environ. Manag. 2000, 26, 251-267. [CrossRef] [PubMed]

100. Fürstenau, C.; Badeck, F.W.; Lasch, P.; Lexer, M.J.; Lindner, M.; Mohr, P.; Suckow, F. Multiple-use forest management in consideration of climate change and the interests of stakeholder groups. Eur. J. For. Res. 2006, 126, 225-239. [CrossRef]

101. Dahal, D.S.; Cao, S. Sustainability Assessment of Community Forestry Practices in Nepal: Literature Review and Recommendations to Improve Community Management. Proc. Natl. Acad. Sci. India Sect. B Biol. Sci. 2015, 87, 1-11. [CrossRef]

102. Dai, L.; Wang, Y.; Su, D.; Zhou, L.; Yu, D.; Lewis, B.J.; Qi, L. Major Forest Types and the Evolution of Sustainable Forestry in China. Environ. Manag. 2011, 48, 1066-1078. [CrossRef] [PubMed]

103. Gupta, S. Forest sustainability and development in hills of Uttarakhand, India: Can they move together? Environ. Dev. Sustain. 2015, 18, 279-294. [CrossRef]

104. Laukkanen, S.; Palander, T.; Kangas, J. Applying voting theory in participatory decision support for sustainable timber harvesting. Can. J. For. Res. 2004, 34, 1511-1524. [CrossRef]

105. Souza, A.F.; Cortez, L.S.R.; Longhi, S.J. Native forest management in subtropical South America: Long-term effects of logging and multiple-use on forest structure and diversity. Biodivers. Conserv. 2012, 21, 1953-1969. [CrossRef]

106. Gulbrandsen, L.H. The Effectiveness of Non-State Governance Schemes: A Comparative Study of Forest Certification in Norway and Sweden. Int. Environ. Agreem. 2005, 5, 125-149. [CrossRef] 
107. Richter, K.; Werner, F.; Althaus, H.-J. Assessment of the Forest Products Industries. In Renewables-Based Technology; Dewulf, J., Van Langenhove, H., Eds.; Wiley: Hoboken, NJ, USA, 2006; pp. 193-208.

108. He, M.; Wu, Z.; Li, W.; Zeng, Y. Forest Certification in Collectively Owned Forest Areas and Sustainable Forest Management: A Case of Cooperative-Based Forest Certification in China. Small-Scale For. 2015, 14, 245-254. [CrossRef]

109. Johnson, P.J.; Borgiel, T.M. CSA's SFM Program: Market access through Sustainable Forest Management; FPAC: Ottawa, ON, Canada, 2003; pp. 1-19.

110. Berg, S.; Fischbach, J.; Bruechert, F.; Poissonnet, M.; Pizzirani, S.; Varet, A.; Sauter, U.H. Towards assessing the sustainability of European logging operations. Eur. J. For. Res. 2012, 131, 81-94. [CrossRef]

111. Graedel, T.E.; Howard-Grenville, J.A. Greening the Industrial Facility. Perspectives, Approaches, and Tools: Chapter 22 Forest Products and Printing; Springer: New York, NY, USA, 2005; pp. 1-617, ISBN 9780387243062.

112. Höglmeier, K.; Weber-Blaschke, G.; Richter, K. Utilization of recovered wood in cascades versus utilization of primary wood-A comparison with life cycle assessment using system expansion. Int. J. Life Cycle Assess. 2014, 19, 1755-1766. [CrossRef]

113. Rivela, B.; Hospido, A.; Moreira, T.; Feijoo, G. Life Cycle Inventory of Particleboard: A Case Study in the Wood Sector (8 pp). Int. J. Life Cycle Assess. 2006, 11, 106-113. [CrossRef]

114. Pingoud, K.; Perälä, A.-L.; Pussinen, A. Carbon dynamics in wood products. Mitig. Adapt. Strateg. Glob. Chang. 2001, 6, 91-111. [CrossRef]

115. Pingoud, K.; Lehtilä, A. Fossil carbon emissions associated with carbon flowsof wood products. Mitig. Adapt. Strateg. Glob. Chang. 2002, 7, 63-83. [CrossRef]

116. Vogtländer, J.G.; Van Der Velden, N.M.; Van Der Lugt, P. Carbon sequestration in LCA, a proposal for a new approach based on the global carbon cycle; cases on wood and on bamboo. Int. J. Life Cycle Assess. 2013, 19, 13-23. [CrossRef]

117. Somarriba, E. Sustainable timber production from uneven-aged shade stands of Cordia alliodora in small coffee farms. Agrofor. Syst. 1990, 10, 253-263. [CrossRef]

118. Chesneau, J.-B.; Le Net, E.; Berg, S. A transport tool to evaluate sustainability impacts of transport processes within the Forest Wood Chain. Eur. J. For. Res. 2012, 131, 73-80. [CrossRef]

119. Rivela, B.; Moreira, M.T.; Feijoo, G. Life cycle inventory of medium density fibreboard. Int. J. Life Cycle Assess. 2007, 12, 143-150. [CrossRef]

120. Lindqvist, M.; Palme, U.; Lindner, J.P. A comparison of two different biodiversity assessment methods in LCA-A case study of Swedish spruce forest. Int. J. Life Cycle Assess. 2015, 21, 190-201. [CrossRef]

121. Allacker, K.; Souza, D.M.D.; Sala, S. Land use impact assessment in the construction sector: an analysis of LCIA models and case study application. Int. J. Life Cycle Assess. 2014, 19, 1799-1809. [CrossRef]

122. Silva, D.; Lahr, F.; Pavan, A.; Saavedra, Y.; Mendes, N.; Sousa, S.; Sanches, R.; Ometto, A. Do wood-based panels made with agro-industrial residues provide environmentally benign alternatives? An LCA case study of sugarcane bagasse addition to particle board manufacturing. Int. J. Life Cycle Assess. 2014, 19, 1767-1778. [CrossRef]

123. Wolfslehner, B.; Bruechert, F.; Fischbach, J.; Rammer, W.; Becker, G.; Lindner, M.; Lexer, M.J. Exploratory multi-criteria analysis in sustainability impact assessment of forest-wood chains: The example of a regional case study in Baden-Wurttemberg. Eur. J. For. Res. 2012, 131, 47-56. [CrossRef]

124. Eriksson, L.O.; Gustavsson, L.; Hänninen, R.; Kallio, M.; Lyhykäinen, H.; Pingoud, K.; Pohjola, J.; Sathre, R.; Solberg, B.; Svanaes, J.; et al. Climate change mitigation through increased wood use in the European construction sector-towards an integrated modelling framework. Eur. J. For. Res. 2011, 131, 131-144. [CrossRef]

125. Eshun, J.F.; Potting, J.; Leemans, R. Inventory analysis of the timber industry in Ghana. Int. J. Life Cycle Assess. 2010, 15, 715-725. [CrossRef]

126. Canto-Perello, J.; Martinez-Garcia, M.P.; Curiel-Esparza, J.; Martin-Utrillas, M. Implementing Sustainability Criteria for Selecting a Roof Assembly Typology in Medium Span Buildings. Sustainability 2015, 7, 6854-6871. [CrossRef]

127. Eštoková, A.; Porhinčák, M. Reduction of primary energy and $\mathrm{CO}_{2}$ emissions through selection and environmental evaluation of building materials. Theor. Found. Chem. Eng. 2012, 46, 704-712. [CrossRef] 
128. Lewandowska, A.; Noskowiak, A.; Pajchrowski, G.; Zarebska, J. Between full LCA and energy certification methodology-A comparison of six methodological variants of buildings environmental assessment. Int. J. Life Cycle Assess. 2014, 20, 9-22. [CrossRef]

129. Mequignon, M.; Adolphe, L.; Thellier, F.; Ait Haddou, H. Impact of the lifespan of building external walls on greenhouse gas index. Build. Environ. 2013, 59, 654-661. [CrossRef]

130. Nordby, A.S.; Shea, A.D. Building Materials in the Operational Phase. J. Ind. Ecol. 2013, 17, $763-776$. [CrossRef]

131. Passer, A.; Kreiner, H.; Maydl, P. Assessment of the environmental performance of buildings: A critical evaluation of the influence of technical building equipment on residential buildings. Int. J. Life Cycle Assess. 2012, 17, 1116-1130. [CrossRef]

132. Petersen, A.K.; Solberg, B. Greenhouse Gas Emissions and Costs over the Life Cycle of Wood and Alternative Flooring Materials. Clim. Chang. 2004, 64, 143-167. [CrossRef]

133. Spindler, E.J. Sustainable development: How to weigh both economical and ecological cost? A new strategy for a combined optimization. J. Vinyl. Addit. Technol. 2001, 7, 84-89. [CrossRef]

134. Bolin, C.A.; Smith, S. Life cycle assessment of ACQ-treated lumber with comparison to wood plastic composite decking. J. Clean. Prod. 2011, 19, 620-629. [CrossRef]

135. Feifel, S.; Stübs, O.; Seibert, K.; Hartl, J. Comparing wood-polymer composites with solid wood: The case of sustainability of terrace flooring. Eur. J. Wood Prod. 2015, 73, 829-836. [CrossRef]

136. Gasol, C.M.; Farreny, R.; Gabarrell, X.; Rieradevall, J. Life cycle assessment comparison among different reuse intensities for industrial wooden containers. Int. J. Life Cycle Assess. 2008, 13, 421-431. [CrossRef]

137. Huang, H.; Zhang, L.; Liu, Z.; Sutherland, J.W. Multi-criteria decision making and uncertainty analysis for materials selection in environmentally conscious design. Int. J. Adv. Manuf. Technol. 2010, 52, 421-432. [CrossRef]

138. Dong, Y.H.; Ng, S.T. A modeling framework to evaluate sustainability of building construction based on LCSA. Int. J. Life Cycle Assess. 2016, 21, 555-568. [CrossRef]

139. Englin, J.; Callaway, J.M. Environmental impacts of sequestering carbon through forestation. Clim. Chang. 1995, 31, 67-78. [CrossRef]

140. Fehrenbach, H.; Grahl, B.; Giegrich, J.; Busch, M. Hemeroby as an impact category indicator for the integration of land use into life cycle (impact) assessment. Int. J. Life Cycle Assess. 2015, 20, 1511-1527. [CrossRef]

141. Fernández, M.; Martínez, A.; Alonso, A.; Lizondo, L. A mathematical model for the sustainability of the use of cross-laminated timber in the construction industry: The case of Spain. Clean Technol. Environ. Policy 2014, 16, 1625-1636. [CrossRef]

142. González-García, S.; Feijoo, G.; Widsten, P.; Kandelbauer, A.; Zikulnig-Rusch, E.; Moreira, M.T. Environmental performance assessment of hardboard manufacture. Int. J. Life Cycle Assess. 2009, 14, 456-466. [CrossRef]

143. Ingerson, A. Carbon storage potential of harvested wood: Summary and policy implications. Mitig. Adapt. Strateg. Glob. Chang. 2010, 16, 307-323. [CrossRef]

144. Kouchaki-Penchah, H.; Sharifi, M.; Mousazadeh, H.; Zarea-Hosseinabadi, H.; Nabavi-Pelesaraei, A. Gate to gate life cycle assessment of flat pressed particleboard production in Islamic Republic of Iran. J. Clean. Prod. 2016, 112, 343-350. [CrossRef]

145. Puelzl, H.; Prokofieva, I.; Berg, S.; Rametsteiner, E.; Aggestam, F.; Wolfslehner, B. Indicator development in sustainability impact assessment: Balancing theory and practice. Eur. J. For. Res. 2012, 131, 35-46. [CrossRef]

146. Schaubroeck, T.; Staelens, J.; Verheyen, K.; Muys, B.; Dewulf, J. Improved ecological network analysis for environmental sustainability assessment; a case study on a forest ecosystem. Ecol. Model. 2012, 247, 144-156. [CrossRef]

147. Takano, A.; Hafner, A.; Linkosalmi, L.; Ott, S.; Hughes, M.; Winter, S. Life cycle assessment of wood construction according to the normative standards. Eur. J. Wood Prod. 2015, 73, 299-312. [CrossRef]

148. Tarantini, M.; Loprieno, A.D.; Porta, P.L. A life cycle approach to Green Public Procurement of building materials and elements: A case study on windows. Energy 2011, 36, 2473-2482. [CrossRef]

149. Guardigli, L.; Monari, F.; Bragadin, M.A. Assessing Environmental Impact of Green Buildings through LCA Methods: Acomparison between Reinforced Concrete and Wood Structures in the European Context. Procedia. Eng. 2011, 21, 1199-1206. [CrossRef] 
150. Goedkoop, M.; Spriensma, R. The Eco-indicator 99: A Damage Oriented Method for Life Cycle Impact Assessment; Methodology Report; PRé Consultants B.V.: Amersfoort, The Netherland, 2001; pp. 1-144.

151. Goedkoop, M.; Heijungs, R.; Huijbregts, M.; Schryver, A.D.; Struijs, J.; Van Zelm, R. ReCiPe 2008: A Life Cycle Impact Assessment Method Which Comprises Harmonised Category Indicators at the Midpoint and Endpoint Level; First edition Report I: Characterisation; RIVM: Bilthoven, NL, 2009; pp. 1-132.

152. Jolliet, O.; Margni, M.; Charles, R.; Humbert, S.; Payet, J.; Rebitzer, G.; Rosenbaum, R. IMPACT 2002+: A new life cycle impact assessment methodology. Int. J. Life Cycle Assess. 2003, 8, 324. [CrossRef]

153. Carpenter, A.; Jambeck, J.R.; Gardner, K.; Weitz, K. Life Cycle Assessment of End-of-Life Management Options for Construction and Demolition Debris. J. Ind. Ecol. 2012, 17, 396-406. [CrossRef]

154. Slocombe, D.S.; van Bers, C. Ecological design criteria for a sustainable Canadian society. Environmentalist 1992, 12, 243-254. [CrossRef]

155. Ianni, E.; Geneletti, D. Applying the Ecosystem Approach to Select Priority Areas for Forest Landscape Restoration in the Yungas, Northwestern Argentina. Environ. Manag. 2010, 46, 748-760. [CrossRef] [PubMed]

156. Zuo, K.; Potangaroa, R.; Wilkinson, S.; Rotimi, J.O.B. A project management prospective in achieving a sustainable supply chain for timber procurement in Banda Aceh, Indonesianull. Int. J. Manag. Proj. Bus. 2009, 2, 386-400. [CrossRef]

157. Werner, F.; Richter, K. Wooden building products in comparative LCA. Int. J. Life Cycle Assess. 2007, 12, 470-479. [CrossRef]

158. Spangenberg, J.H. Institutional sustainability indicators: An analysis of the institutions in Agenda 21 and a draft set of indicators for monitoring their effectivity. Sustain. Dev. 2002, 10. [CrossRef]

159. Vogelpohl, T.; Aggestam, F. Public policies as institutions for sustainability: Potentials of the concept and findings from assessing sustainability in the European forest-based sector. Eur. J. For. Res. 2011, 131, 57-71. [CrossRef]

160. Nabuurs, G.J.; Thürig, E.; Heidema, N.; Armolaitis, K.; Biber, P.; Cienciala, E.; Kaufmann, E.; Mäkipää, R.; Nilsen, P.; Petritsch, R.; et al. Hotspots of the European forests carbon cycle. For. Ecol. Manag. 2008, 256, 194-200. [CrossRef]

161. Pan, Y.; Birdsey, R.A.; Fang, J.; Houghton, R.; Kauppi, P.E.; Kurz, W.A.; Phillips, O.L.; Shvidenko, A.; Lewis, S.L.; Canadell, J.G.; et al. A Large and Persistent Carbon Sink in the World's Forests. Science 2011, 333, 988-993. [CrossRef] [PubMed]

162. Wolfslehner, B.; Huber, P.; Lexer, M.J. Smart use of small-diameter hardwood-A forestry-wood chain sustainability impact assessment in Austria. Scand. J. For. Res. 2013, 28, 184-192. [CrossRef]

163. Knauf, M. A multi-tiered approach for assessing the forestry and wood products industries' impact on the carbon balance. Carbon Balanc. Manag. 2015, 10, 1-11. [CrossRef] [PubMed]

164. O'Sullivan, O.S.; Hopkinson, L.; Crockatt, M.E.; Laird, P.; Bebber, D.P. Stable forest carbon stocks support current assumption of biogenic carbon neutrality in the case of European-manufactured beverage cartons. Int. J. Life Cycle Assess. 2015, 21, 118-128. [CrossRef]

165. Gustavsson, L.; Sathre, R. Energy and $\mathrm{CO}_{2}$ analysis of wood substitution in construction. Clim. Chang. 2010, 105, 129-153. [CrossRef]

166. Nebel, B.; Zimmer, B.; Wegener, G. Life Cycle Assessment of Wood Floor Coverings-A Representative Study for the German Flooring Industry (11 pp). Int. J. Life Cycle Assess. 2006, 11, 172-182. [CrossRef]

167. Intergovernmental Panel on Climate Change (IPCC). Guidelines for National Greenhouse Gas Inventories: Chapter 1 Introduction. Volume 4: Agriculture, Forestry and Other Land Use; IPCC: Geneva, Switzerland, 2006; pp. 1-21. Available online: http:/ / www.ipcc-nggip.iges.or.jp/public/2006gl/vol4.html (accessed on 31 August 2017).

168. Sathre, R.; Gustavsson, L. Energy and carbon balances of wood cascade chains. Resour. Conserv. Recy. 2006, 47, 332-355. [CrossRef]

169. Milà i Canals, L.; Bauer, C.; Depestele, J.; Dubreuil, A.; Knuchel, R.F.; Gaillard, G.; Michelsen, O.; Müller-Wenk, R.; Rydgren, B. Key elements in a framework for land use impact assessment within LCA. Int. J. Life Cycle Assess. 2007, 12, 5-15. [CrossRef]

170. Börjesson, P.; Gustavsson, L. Greenhouse gas balances in building construction: Wood versus concrete from life-cycle and forest land-use perspectives. Energy Policy 2000, 28, 575-588. [CrossRef]

171. Eshun, J.F.; Potting, J.; Leemans, R. LCA of the timber sector in Ghana: Preliminary life cycle impact assessment (LCIA). Int. J. Life Cycle Assess. 2011, 16, 625-638. [CrossRef] 
172. Curran, M.; Baan, L.D.; Schryver, A.M.D.; Van Zelm, R.; Hellweg, S.; Koellner, T.; Sonnemann, G.; Huijbregts, M.A.J. Toward meaningful end points of biodiversity in life cycle assessment. Environ. Sci. Technol. 2011, 45, 70-79. [CrossRef] [PubMed]

173. Souza, D.M.; Teixeira, R.F.M.; Ostermann, O.P. Assessing biodiversity loss due to land use with Life Cycle Assessment: Are we there yet? Glob. Chang. Biol. 2015, 21, 32-47. [CrossRef] [PubMed]

174. Souza, D.M.D.; Flynn, D.F.B.; DeClerck, F.; Rosenbaum, R.K.; Melo Lisboa, H.D.; Koellner, T. Land use impacts on biodiversity in LCA: Proposal of characterization factors based on functional diversity. Int. J. Life Cycle Assess. 2013, 18, 1231-1242. [CrossRef]

175. Launiainen, S.; Futter, M.N.; Ellison, D.; Clarke, N.; Finér, L.; Högbom, L.; Laurén, A.; Ring, E. Is the Water Footprint an Appropriate Tool for Forestry and Forest Products: The Fennoscandian Case. Ambio 2013, 43, 244-256. [CrossRef] [PubMed]

176. Glazyrina, I.P.; Faleichik, L.M.; Yakovleva, K.A. Socioeconomic effectiveness and "green" growth of regional forest use. Geogr. Nat. Resour. 2015, 36, 327-334. [CrossRef]

177. Tsang, M.; Meyer, D.; Hawkins, T.; Ingwersen, W.; Sayre, P. Life cycle assessment for emerging materials: Case study of a garden bed constructed from lumber produced with three different copper treatments. Int. J. Life Cycle Assess. 2014, 19, 1345-1355. [CrossRef]

178. Bolin, C.A.; Smith, S.T. Life cycle assessment of borate-treated lumber with comparison to galvanized steel framing. J. Clean. Prod. 2011, 19, 630-639. [CrossRef]

179. Organisation for Economic Co-Operation and Development. Interconnected Economies: Benefiting from Global Value Chains; OECD: Paris, France, 2013; pp. 1-269, ISBN 9264189564.

180. Ximenes, F.A.; Grant, T. Quantifying the greenhouse benefits of the use of wood products in two popular house designs in Sydney, Australia. Int. J. Life Cycle Assess. 2013, 18, 891-908. [CrossRef]

181. Owsianiak, M.; Laurent, A.; Bjørn, A.; Hauschild, M.Z. IMPACT 2002+, ReCiPe 2008 and ILCD's recommended practice for characterization modelling in life cycle impact assessment: A case study-based comparison. Int. J. Life Cycle Assess. 2014, 19, 1007-1021. [CrossRef]

182. Teixeira, C.E.; Sartori, L.; Finotti, A.R. Comparative environmental performance of semi-trailer load boxes for grain transport made of different materials. Int. J. Life Cycle Assess. 2010, 15, 212-220. [CrossRef]

183. Lipušček, I.; Bohanec, M.; Oblak, L.; Stirn, L.Z. A multi-criteria decision-making model for classifying wood products with respect to their impact on environment. Int. J. Life Cycle Assess. 2010, 15, 359-367. [CrossRef]

184. Cowell, S.J.; Clift, R. A methodology for assessing soil quantity and quality in life cycle assessment. J. Clean. Prod. 2000, 8, 321-331. [CrossRef]

185. Jönsson, A. Including the use phase in LCA of floor coverings. Int. J. Life Cycle Assess. 1999, 4, 321-328. [CrossRef]

186. Karjalainen, T.; Zimmer, B.; Berg, S.; Welling, J.; Schwaiger, H.; Finér, L.; Cortijo, P. Energy, Carbon and Other Material Flows in the Life Cycle Assessment of Forestry and Forest Products: Achievements of the Working Group 1 of the COST Action E9; Discussion Paper 10; EFI: Joensuu, Finland, 2001; pp. 1-68.

187. Werner, F.; Althaus, H.-J.; Richter, K.; Scholz, R.W. Post-consumer waste wood in attributive product LCA. Int. J. Life Cycle Assess. 2007, 12, 160-172. [CrossRef]

188. González-García, S.; Silva, F.J.; Moreira, M.T.; Pascual, R.C.; Lozano, R.G.; Gabarrell, X.; Rieradevall i Pons, J.; Feijoo, G. Combined application of LCA and eco-design for the sustainable production of wood boxes for wine bottles storage. Int. J. Life Cycle Assess. 2011, 16, 224-237. [CrossRef]

189. Finnveden, G.; Hauschild, M.Z.; Ekvall, T.; Guinée, J.; Heijungs, R.; Hellweg, S.; Koehler, A.; Pennington, D.; Suh, S. Recent developments in Life Cycle Assessment. J. Environ. Manag. 2009, 91, 1-21. [CrossRef] [PubMed]

190. Sandin, G.; Peters, G.M.; Svanström, M. Life cycle assessment of construction materials: The influence of assumptions in end-of-life modelling. Int. J. Life Cycle Assess. 2013, 19, 723-731. [CrossRef]

191. Kovacic, I.; Waltenbereger, L.; Gourlis, G. Tool for life cycle analysis of facade-systems for industrial buildings. J. Clean. Prod. 2015, 130, 260-272. [CrossRef]

192. Steubing, B.; Mutel, C.; Suter, F.; Hellweg, S. Streamlining scenario analysis and optimization of key choices in value chains using a modular LCA approach. Int. J. Life Cycle Assess. 2016, 21, 510-522. [CrossRef]

193. Niero, M.; Di Felice, F.; Ren, J.; Manzardo, A.; Scipioni, A. How can a life cycle inventory parametric model streamline life cycle assessment in the wooden pallet sector? Int. J. Life Cycle Assess. 2014, 19, 901-918. [CrossRef] 
194. Sinha, A.; Gupta, R.; Kutnar, A. Sustainable Development and Green Buildings. Drvna Industrija 2013, 64, 45-53. [CrossRef]

195. Saravia-Cortez, A.M.; Herva, M.; Garcia-Dieguez, C.; Roca, E. Assessing environmental sustainability of particleboard production process by ecological footprint. J. Clean. Prod. 2013, 52, 301-308. [CrossRef]

196. Bach, V.; Berger, M.; Finogenova, N.; Finkbeiner, M. Assessing the Availability of Terrestrial Biotic Materials in Product Systems (BIRD). Sustainability 2017, 9, 137. [CrossRef] 